\title{
New benzophenone-derived bisphosphonium salts as leishmanicidal leads targeting mitochondria through inhibition of respiratory complex II
}

\author{
J. Román Luque-Ortega, ${ }^{1, \dagger}$ Peter Reuther, ${ }^{1, \dagger}$ Luis Rivas, ${ }^{1, *}$ and Christophe Dardonville ${ }^{2, *}$ \\ ${ }^{1}$ Centro de Investigaciones Biológicas, CSIC, Ramiro de Maeztu 9, E-28040 Madrid, Spain. \\ ${ }^{2}$ Instituto de Química Médica, CSIC, Juan de la Cierva 3, E-28006 Madrid, Spain.
}

TITLE RUNNING HEAD New leishmanicidal benzophenone bisphosphonium salts

* To whom correspondence should be addressed. Phone: +34 912587490 (C.D.), +34 918373112 , \# 4234 (L. R.); Fax +34 915644853 (C.D.), +34 915627518 (L. R.); E-mail: dardonville@iqm.csic.es (C.D.), luis.rivas@cib.csic.es (L. R.).

${ }^{\dagger}$ Both authors contributed equally.

$\mathbf{a}$

\footnotetext{
${ }^{a}$ Abbreviations: $\Delta \Psi_{\mathrm{m}}$, mitochondrial membrane potential; BSA, bovine seroalbumin; DMNPEluciferin, [D-luciferin, 1-(4,5-dimethoxy-2-nitrophenyl) ethyl ester]; FCCP, carbonyl cyanide $p$ trifluoromethoxyphenylhydrazone; HBSS-Glc, Hanks' balanced salt solution plus $10 \mathrm{mM}$ Dglucose; $\mathrm{LC}_{50}$, drug concentration required to inhibit 50\% of parasite proliferation; MTT, [3-(4,5dimethylthiazol-2-yl)-2,5-diphenyltetrazolium] bromide; PI, propidium iodide; rhodamine 123, [2(6-amino-3-imino-3H-xanthen-9-yl)benzoic acid methyl ester, chloride]; S.D., Standard deviation; SDS, sodium dodecyl sulfate.
} 
Abstract. A set of benzophenone-derived bisphosphonium salts was synthesized and assayed for lethal activity on the human protozoan parasite Leishmania. A subset of them mostly characterized by phosphonium substituents with an intermediate hydrophobicity, inhibited parasite proliferation at low micromolar range of concentrations. The best of this subset, 4,4'-bis((tri-n-pentyl phosphonium)methyl)benzophenone dibromide, showed a very scarce toxicity on mammalian cells. This compound targets complex II of the respiratory chain of the parasite, based on: i) a dramatically swollen mitochondrion in treated parasites; ii) fast decrease of cytoplasmic ATP; iii) a decrease of the electrochemical mitochondrial potential, and iv) inhibition of the oxygen consumption rate using succinate as substrate. Thus this type of compounds represents a new lead in the development of leishmanicidal drugs.

KEYWORDS: bisphosphonium, benzophenone, Leishmania, mitochondria, succinate dehydrogenase, chemotherapy. 


\section{Introduction}

Leishmaniasis encompasses the different clinical manifestations caused by infection with the protozoan species belonging to the genus Leishmania. It ranges from the cutaneous form, in many cases self-healing, to the visceral leishmaniasis caused by species of the donovani complex, mortal if untreated. According to WHO estimations, 12 million people are infected worldwide, with 2 million new cases per year, from which 500,000 corresponds to the visceral form (http://www.who.int/leishmaniasis/burden/en/). Nowadays, chemotherapy is the only effective way to fight the disease. Until recently, first-line drugs were constituted almost exclusively by pentavalent organic antimonials; aside from their intrinsic high toxicity, their efficacy is threatened by rampant resistance. ${ }^{1}$ In fact, they are progressively being replaced by either liposomal formulations of amphotericin $\mathrm{B}$, despite their high cost, ${ }^{2}$ or miltefosine, the first successful oral drug against the visceral form of leishmaniasis. ${ }^{3}$ Nevertheless, the paucity of new leads in the pipeline is a worrisome scenario, raising concern about the near future. Thus, the search and development of new leads is an urgent priority. ${ }^{4}$

During the screening of in-house made libraries of aromatic and aliphatic dicationic derivatives against Trypanosoma brucei, ${ }^{5,6}$ the trypanocidal effect of the bisphosphonium derivative 4,4'-bis((tri-n-pentylphosphonium)methyl)benzophenone dibromide ${ }^{5}$ was discovered. This compound showed a good trypanocidal activity in vitro with a low DNA-binding affinity, ${ }^{7}$ in contrast to the high affinity of its guanidine counterpart, also trypanocidal. Previously, other authors reported for benzyltriphenyl phosphonium derivatives cidal activities on animal infections by trypanosomatids such as T. brucei rhodesiense ${ }^{8,9}, T$. cruzi (II, Chart 1), ${ }^{10}$ and Leishmania mexicana. ${ }^{11}$ However, the literature about the pharmacological applications of phosphonium derivatives is relatively scarce, encompassing three major fields mainly. The first one consists of phosphonium compounds, such as $p$-xylylene bis(triphenylphosphonium), ${ }^{12}$ or 
poly(methylene)bis(triphenylphosphonium salt (I and III, Chart 1), which showed a marked anticholinesterase and anticholinergic activities on Schistosoma mansoni. ${ }^{13}$ In fact, the phosphonium analog of choline is metabolized and incorporated into phospholipids in mammalian cells without apparent toxicity. ${ }^{14,15}$

A second group of phosphonium compounds is characterized by a strong amphipathic character endowed by the presence of, at least, one long alkyl chain substituent. They were extensively used as biocides, either in monomeric ${ }^{16}$ or polymeric form. ${ }^{17-19}$ They work as cationic detergents, disrupting the cell membrane. Some specificity for this process is achieved by profiting the higher anionic character of cell membranes on prokaryotes and lower eukaryotes (reviewed in $\left.{ }^{20}\right)$.

Finally, some phosphonium derivatives act as lipophilic ions with a delocalized charge and enhanced hydrophobicity. These characteristics afford their transfer across biological membranes despite their cationic nature, with a privileged accumulation in organelles with a strong electrochemical potential, such as mitochondria. ${ }^{21-23}$ Hence, the massive accumulation of these lipophilic cations into mitochondria, may by itself lead to mitochondrial dysfunction, which in turn will trigger the apoptotic mitochondrial pathway (reviewed in ${ }^{24}$ ). This is especially relevant in transformed cells, with a higher $\Delta \Psi_{\mathrm{m}}{ }^{\mathrm{a}}$ than their non-transformed counterparts. ${ }^{25,}{ }^{26}$ As far as Leishmania is concerned, the above mentioned properties of phosphonium derivatives are particularly relevant if one consider the strong anionic character of the parasite plasma membrane ${ }^{27}$ and the key role of mitochondria in the bioenergetics of this parasite. This could in turn represent a target for antileishmanial chemotherapy. To assess this hypothesis, we have synthesized and assayed a number of bisphosphonium benzophenone derivatives bearing different substituents on the phosphonium moieties (IV, Chart 1). As the DNA-binding properties of some of these compounds can not fully account for their trypanocidal effects, and likely for their leishmanicidal activities, ${ }^{7}$ we set out to study other alternative mechanisms. In tune with the aforementioned 
properties of this class of compounds, their effects on plasma membrane integrity and mitochondrial functionality in Leishmania were studied in detail. By complementary bioenergetics and morphological approaches, we have defined the impairment of mitochondrial functionality, as the basis for the leishmanicidal mechanism of bisphosphonium benzophenones, exemplified by 7 , the best within this series. This compound severely impaired mitochondrial ATP synthesis through inhibition of the respiratory complex II (succinate dehydrogenase).

\section{Results}

Chemistry. The bisphosphonium salts 1-19 were synthesized by reaction of 4,4'bisbromomethylbenzophenone with the corresponding phosphine in either anhydrous DMF or anhydrous toluene (Scheme 1). The bisphosphonium salts were isolated with satisfactory yields by crystallization from the reaction mixture. All the starting phosphines were commercially available except tripentylphosphine which was prepared as previously reported. ${ }^{5}$ The substitution pattern $\left(\mathrm{R}_{1}\right.$, $\mathrm{R}_{2}$, and $\mathrm{R}_{3}$ ) of compounds $\mathbf{1 - 1 9}$ is shown in Table 1 .

Cytotoxicity against Leishmania Parasites. The reduction of MTT [3-(4,5dimethylthiazol-2-yl)-2,5-diphenyltetrazolium bromide] by living cells constitutes a suitable parameter to assess the viability in an extensive range of cell lines, including Leishmania. ${ }^{28}$ As such, the capability of bisphosphonium salts to inhibit MTT reduction by Leishmania parasites was used to assess the potential leishmanicidal activity of these compounds. The results were compiled in Table 1. From the initial set of 19 bisphosphonium compounds, 11 showed a $\mathrm{LC}_{50}$ on $L$. donovani promastigotes at the low micromolar range. Under identical criteria, the same subset resulted active on L. pifanoi axenic amastigotes, except 19, with a $\mathrm{LC}_{50}$ higher than $50 \mu \mathrm{M}$, the cutoff established in the present study to select the active candidates (Table 1). Interestingly, amastigotes, the pathological form of the parasite in vertebrates, resulted more susceptible than promastigotes, with the sole exception of compound 14 and the aforementioned 19. The results 
underscore certain structural features modulating the leishmanicidal activity. For compounds with homoalkyl groups, the activity was restricted to those with a narrow range of substituents, from 5 to 8 carbon length, suggesting an important role for hydrophobicity, tightly limited in values. Compound 7, with n-pentyl substituents, showed the highest potency. The combination of two alkyl groups plus an aromatic substituent was not enough to recover activity for methyl (10) or ethyl (11) substituents, but a better activity was achieved when two phenyl groups $(\mathbf{1 3}, \mathbf{1 4})$ or cyclohexyl substituents were present (compound 12). The triphenyl phosphonium $(\mathbf{1 5})$ or diphenyltolyl $(\mathbf{1 7}, \mathbf{1 8})$ compounds showed activities very close to the $n$-pentyl substituted compound. In particular, the diphenyl-p-tolyl analogue (18) displayed the second best activity of the whole series. Inclusion of a heterocycle was well tolerated for 2-pyridyl (16), but impaired activity in more than one log order for furanyl (19). As compound 7 turned out to be the most active molecule, both on promastigotes and amastigotes, its toxicity on mammalian cells was assayed. The $\mathrm{LC}_{50}$ of 7 on mouse peritoneal macrophages was $28.6 \pm 4.8 \mu \mathrm{M}$. This represents a therapeutic index of 28 , defined as the ratio between the respective $\mathrm{LC}_{50 \mathrm{~s}}$ for mammalian cells and for amastigotes, the pathological form in mammals. According to its highest leishmanicidal activity and scarce toxicity on mammalian cells, compound 7 was selected for the subsequent set of assays dealing with its mechanism of action.

Decrease of Intracellular ATP Levels. The maintenance of an adequate intracellular ATP level is essential for cellular homeostasis. The in vivo luminescence of 3-Luc promastigotes affords a real-time monitorization of changes in the cytoplasmic ATP pool. ${ }^{29}$ Accordingly, compound 7 caused a drop of the luminescence of the 3-Luc strain in a concentration-dependent manner, reaching the end-point 10-15 min after addition (Figure 1). Altogether, these results suggest a decrease of the cytoplasmic ATP pool caused by 7 .

Maintenance of Plasma Membrane Integrity. The drop of intracellular ATP observed in the previous assay can be caused either by inhibition of mitochondrial ATP synthesis, essential in the bioenergetics of Leishmania, otherwise by permeabilization of the parasite plasma membrane, 
leading to ATP release or its futile hydrolysis by ionic pumps, in an attempt to recover the initial ionic gradients. The latter alternative was examined by monitoring the entrance of the vital dye SYTOX green. Even at $25 \mu \mathrm{M}$, i.e. a 25 -fold higher concentration than its $\mathrm{LC}_{50}$, compound 7 was unable to produce any significant increase of SYTOX green fluorescence, ruling out damage to the plasma membrane integrity (data not shown).

Morphological Alterations Induced by Compound 7. In a further step, the morphological damage inflicted to the promastigotes by compound 7 was visualized by transmission electron microscopy. Electron micrographs showed an extremely swollen mitochondrion for parasites treated with 7 at $5 \mu \mathrm{M}$ (Figure 2). This organelle appeared as a huge, electron translucent vacuole, occupying a large fraction of the intracellular space. In fact, mitochondrion was only identified by the presence of the kinetoplast, the mitochondrial network of concatenated DNA circles, characteristic of trypanosomatids. Furthermore, the plasma membrane appeared mostly intact, which confirmed the above results with SYTOX green.

Effect on Mitochondrial Functionality. The cumulative evidence of the results obtained by the two previous techniques, prompted us to get a deeper insight into mitochondrial functionality. In a first step, we examined the variation of $\Delta \Psi_{\mathrm{m}}$, essential to drive the mitochondrial ATP synthesis, assessed by rhodamine 123 accumulation in promastigotes, and monitored by cytofluorometry. The $\Delta \Psi_{\mathrm{m}}$-driven accumulation of rhodamine showed a consisting decreasing trend after incubation with growing concentrations of 7 (Figure 3). The same result was obtained when the incubation was carried out for $4 \mathrm{~h}$ in HBSS, conditions used for luminescence and cytotoxicity (data not shown). Rhodamine 123 accumulation also decreased around 50\% for most of the remaining leishmanicidal benzophenone-derived bisphosphonium compounds at their respective $\mathrm{LC}_{50}$ (Table 1), confirming mitochondrial damage inflicted by these drugs. Nevertheless, compounds 13, 14 and 16, did not follow the same trend (Table 1), suggesting alternative targets. 
In a step forward, we set out to define the molecular target of 7 in the mitochondrial ATP synthesis. To afford free access of specific substrates and inhibitors to the different complexes of the respiratory chain, digitonin-permeabilized parasites were used. The integrity of the inner mitochondrial membrane was preserved, as after ADP addition, the respiration increased recovering state 3, in which ADP is not longer the limiting substrate for oxidative phosphorylation. At this state, oxygen consumption rate of digitonin-permeabilized parasites was $9.4 \mathrm{nmol} \times \mathrm{min}^{-1} \times 10^{-8}$ cells (Figure 4B). The addition of $16 \mu \mathrm{M}$ of compound 7 to digitonized parasites leads to a full inhibition of the oxygen consumption rate using succinate as substrate (Figure 4B). Addition of 10 $\mu \mathrm{M}$ FCCP, a mitochondrial uncoupler, did not revert this inhibition, ruling out any specific inhibition of 7 on $\mathrm{F}_{1} \mathrm{~F}_{0}-\mathrm{ATPase}$ (Figure $4 \mathrm{~A}$ ). In contrast, addition of TMPD-ascorbate, an electron donor to cytochrome $\mathrm{c}^{30}$ restored the oxygen consumption rate at $50 \%$ of the initial value (Figure 4B). This excludes cytochrome c oxidase (complex IV) as the site of inhibition, and circumscribes the potential target upstream cytochrome c (Scheme 2). The oxygen consumption rate inhibited by 7 was partially (33\%) reinstated upon addition of $6.7 \mathrm{mM} \alpha$-glycerophosphate (data not shown), a substrate of complex I. ${ }^{30}$ Consequently, this result ruled out complexes I and III as targets for 7, and supports complex II as the more likely target for this drug. To verify this hypothesis the succinatedependent respiration was inhibited with malonate at the level of complex II, and oxygen consumption was allowed to proceed with $\alpha$-glycerophosphate as the sole substrate through complex I. Under these conditions, i.e. without a functional complex II, compound 7 did not exert any inhibitory effect on the $\alpha$-glycerophosphate-dependent respiration (Figure 4C), pointing at complex II as the main target within oxidative phosphorylation.

Leishmania Killing Involves an Apoptotic Process. Since the mitochondrion plays a pivotal role in the onset of apoptosis in Leishmania, the induction of apoptosis by compound 7 was investigated. 
Overnight incubation of promastigotes with different concentrations of compound 7, lead to an increase in the sub- $\mathrm{G}_{1}$ peak region, accounting for fragmented chromatin, hence of apoptosis (Figure 5). The percentage of promastigotes with a PI fluorescence in the peak region typical of apoptotic cells was $22 \%$ at the $\mathrm{LC}_{50}$, while in parasites treated with miltefosine, a typical apoptosis inducer in Leishmania $^{31}$, the percentage was $25 \%$ at $15 \mu \mathrm{M}$, its $\mathrm{LC}_{50}$ on promastigotes (Figure 5).

\section{Discussion.}

The choice of phosphonium substituents with moderate hydrophobicity led to compounds with an intermediate lipophilicity, capable to traverse the plasma membrane and accumulate in organelles driven by electrical potentials. ${ }^{24}$ According to this hydrophobicity criteria for the substituents, from the set of compounds tested, those with leishmanicidal activity belong to this group. The substituents are medium length alkyl chains (5-8 carbons), aryl groups, or a combination of both. Nevertheless, the literature regarding these compounds is mostly based on the presence of a single phosphonium group in the molecule. Actually, the uptake of dications may be impaired by the double charge present in the molecule. In fact, the desolvatation process (i.e., energy required to remove solvating water molecules) is the main energy demand to move a cation from the aqueous medium to the hydrophobic lipid membrane. ${ }^{21}$ In practical terms, the bisphosphonium cations require a higher threshold hydrophobicity than monophosphonium compounds to traverse the membrane ${ }^{21}$ which for the set of compounds assayed was provided by the benzophenone scaffold connecting the two phosphonium moieties. As the entrance of the vital dye SYTOX green into parasites is nil, even at concentrations higher than those required for full lethality, plasma membrane permeabilization was ruled out as a major cause of parasite killing. Thereby, the lethal activity must involve intracellular targets, thus, uptake of compound $\mathbf{7}$ and other active compounds by the parasite. Accordingly, the balance of hydrophobicity with charge, required for the translocation across the membrane, is finely tuned. In fact, changes in the overall polarity of the 
whole molecule, achieved with a single incorporation of a heterocycle with slightly higher polarity than the phenyl substituent, impaired (2-pyridinyl, 16), or almost abrogated (2-furanyl, 19) leishmanicidal activity. The same happened when hydrophobicity was decreased for short alkyl substituents (1-6, 10-11). This exquisite modulation by subtle changes in the hydrophobicity of phosphonium substituents has been employed to optimize the mitochondrial uptake of MitoQ, consisting in an antioxidant ubiquinone coupled to a phosphonium group. ${ }^{31,32}$

The cellular uptake and accumulation for phosphonium compounds is driven by electrical potential; ${ }^{22}$ hence the plasma membrane potential and, in a further step the higher $\Delta \Psi_{\mathrm{m}}$ of the mitochondrion will lead to a massive accumulation of these compounds in this organelle. ${ }^{23,24,33}$ Although in this work we did not attempt to define the intracellular distribution of compound 7 , from the experimental results it was concluded beyond reasonable doubt that mitochondria constitutes an essential target for that compound. This is demonstrated by morphological data, obtained from micrographs were the mitochondrion of Leishmania appeared dramatically swollen in parasites treated with 7 . This result was validated from a functional perspective; 7 provokes a prominent decrease of cytoplasmic ATP level, as assessed in real-time by the rapid decay of luminescence of living 3-Luc parasites. ${ }^{29}$ Once the leakage of intracellular ATP or its enhanced hydrolysis associated to membrane permeabilization were discarded as the reason for these effects, impairment of ATP synthesis, essentially of mitochondrial origin in Leishmania, came out as the most feasible target for compound 7. In fact, this compound causes the decrease of $\Delta \Psi_{\mathrm{m}}$, which drives mitochondrial ATP synthesis, a trend also observed for most of the compounds, for which leishmanicidal effect is associated with inhibition of rhodamine 123 accumulation.

Finally, the mitochondrial dysfunction created by 7 was unequivocally pinpointed to the inhibition of complex II, according to the systematic dissection of the functionality of the whole set of components involved in the oxidative phosphorylation process. 
According to experimental data provided by other authors, we surmise two major alternatives to account for the inhibition of complex II; either, an unspecific effect due to a general mitochondrial dysfunction, otherwise, produced by a specific effect of 7 on complex II .

Under the hypothesis of an unspecific origin for the inhibition of complex II by 7 , this would be likely due to the perturbation of the biophysical parameters of the inner mitochondrial membrane after massive $\Delta \Psi_{\mathrm{m}}$-driven insertion of 7 , as a lipophilic phosphonium compound. In fact, the specific tumoricidal activity of phosphonium compounds was based on their larger accumulation in mitochondria, due to the significant higher $\Delta \Psi_{\mathrm{m}}$ in transformed- versus non-transformed cells. ${ }^{24,34-}$ ${ }^{36}$ For Leishmania, the $\Delta \Psi_{\mathrm{m}}$ values reported are rather similar to those for mammalian cells (-150 $\mathrm{mV}$ in L. donovani promastigotes ${ }^{37} \mathrm{vs}-140$ to $-180 \mathrm{mV}$ in mammalian cells ${ }^{38}$ ). Although plasma membrane potential is higher in Leishmania $(c a-100 \text { to }-110 \mathrm{mV})^{39-41}$ than in many typical eukaryotic resting cells $(-30$ to $-60 \mathrm{mV}),{ }^{42}$ the only predicted effect will be a faster transfer of bisphosphonium compounds from the external medium into the intracellular space. Nevertheless, the final mitochondrial accumulation of 7 , driven solely by $\Delta \Psi_{\mathrm{m}}$, will be similar in both types of cells. Additional facts to discard an unspecific effect are provided by the integrity of the inner mitochondrial membrane throughout the time span of the experiment, as well as preservation of the functionality of the rest of the components within the respiratory chain. This is evidenced by the unaltered oxygen consumption rate obtained in the presence of 7 , when the system was artificially fed with substrates outside complex II, i.e. $\alpha$-glycerophosphate and TMPD-ascorbate.

Hence, a specific inhibition of compound 7 on the mitochondrial complex II is the most feasible scenario to account for its leishmanicidal activity. In cancer cells, other lipophilic cations such as rhodamine 123 or AA-1 (thiopyrilium) work by specific inhibition, in this case the $\mathrm{F}_{1} \mathrm{~F}_{0}$-ATPase. ${ }^{25}$ Drugability of complex II in Leishmania has been reported for other compounds ${ }^{43,44}$ also leading to apoptosis of the parasite, ${ }^{43}$ as happens with 7. 
The uniqueness of the complex II of Leishmania as target for 7, may be disputed on the basis of i) its dicationic character will presumably afford binding to either nuclear or kinetoplast DNA, as described for its guanidine homolog, but this possibility was ruled out on the grounds of the poor affinity of 7 for DNA. ${ }^{7}$ ii) Compound 7 is active on the bloodstream forms of the African trypanosome T. b. rhodesiense..$^{5}$ It is well established that the bioenergetic requirements of this form of parasite are fulfilled by glycolysis rather than through oxidative phosphorylation, ${ }^{45}$ as Leishmania does. Nevertheless, for this trypanosomal form the maintenance of a rudimentary mitochondrion with a residual $\Delta \Psi_{\mathrm{m}}$ is essential, although sustained by the electrogenic activity of mitochondrial ATPase ${ }^{46}$ without the concourse of cytochrome-containing complexes. Altogether these data suggest the existence of additional targets aside from complex II, at least for other trypanosomatids.

\section{Conclusions}

Although the potential of phosphonium compounds as leishmanicidal drugs has been previously described for African and American trypanosomes, and very succintly mentioned for L. braziliensis and L. mexicana, this work demonstrates the feasibility of benzophenone-derived bisphosphonium salts as new leishmanicidal lead compounds. A fine modulation of the activity and specificity was achieved by the adequate selection of substituent based on their hydrophobicity. Two additional facts stressed this assertion; first the higher susceptibility of amastigotes, as the pathological form of the parasite in vertebrates, over promastigote; and secondly, compound 7 acts over complex II of the mitochondrial respiratory chain. The importance of this target for Leishmania is highlighted by the total dependence of this parasite on mitochondrial ATP synthesis to fulfill its bioenergetic requirements. Furthermore, in quantitative terms, complex II is the main gate for the metabolic feeding of the respiratory chain. All these items make highly attractive the exploitation of 
bisphosphonium salts as new leishmanicidal leads. Further progress in SAR studies is currently ongoing. 


\section{Experimental Section}

Chemistry. All dry solvents were purchased from Aldrich or Fluka in Sure/Seal bottles. All reactions requiring anhydrous conditions or an inert atmosphere were performed under a positive pressure of $\mathrm{N}_{2}$. All reactions were monitored by HPLC-MS. ${ }^{1} \mathrm{H}$ and ${ }^{13} \mathrm{C}$ NMR spectra were recorded on a Bruker Advance 300 or Varian Inova 400 spectrometer. Chemical shifts of the ${ }^{1} \mathrm{H}$ NMR spectra were internally referenced to the residual proton resonance of the deuterated solvents: $\mathrm{CDCl}_{3}(7.24 \mathrm{ppm})$ and DMSO $(\delta 2.5 \mathrm{ppm}) . J$ values are given in $\mathrm{Hz}$. Chemical shifts of the ${ }^{13} \mathrm{C}$ NMR spectra were referenced to the carbon resonance of the deuterated solvents: $\mathrm{CDCl}_{3}(77.23$ ppm) and DMSO ( $\delta 39.51 \mathrm{ppm})$. Melting points were determined in open capillary tubes with a SMP3-Stuart Scientific apparatus and are uncorrected. The solvent used for crystallization is indicated between brackets. The purity of the compounds was $\geq 95 \%$ as assessed by combustion analysis or HPLC. Elemental analysis was performed on a Heraeus CHN-O Rapid analyzer. Analytical results were within $\pm 0.4 \%$ of the theoretical values unless otherwise noted. Analytical HPLC-MS was run with a Waters Sunfire C18-3.5 $\mu \mathrm{m}(4.6 \times 50 \mathrm{~mm})$ column on a Waters 2695 separation module coupled with a Waters Micromass ZQ spectrometer using electrospray ionization $\left(\mathrm{ES}^{+}\right)$. The following HPLC conditions were used: column temperature $=30{ }^{\circ} \mathrm{C}$, gradient time $=5$ min, $\mathrm{H}_{2} \mathrm{O} / \mathrm{CH}_{3} \mathrm{CN}(90: 10 \rightarrow 0: 100)\left(\mathrm{HCO}_{2} \mathrm{H} 0.1 \%\right)$, flow rate $=1 \mathrm{~mL} / \mathrm{min}, \mathrm{UV}$ detection: diode array $(\lambda=190-400 \mathrm{~nm})$. HRMS spectra were recorded on a QTOF 6520 Agilent Technologies mass spectrometer.

General procedure for the synthesis of the bisphosphonium salts 1-19: a Kimax tube was charged with 4,4'-bis(bromomethyl)benzophenone ${ }^{5}$ (100 mg, $0.272 \mathrm{mmol}$ ) and flushed with argon. Anhydrous DMF (3 mL) was added followed by the phosphine (1.1 mmol, 4 equiv). The tube was flushed with argon, stopped, and the reaction mixture was stirred at $110^{\circ} \mathrm{C}$ for $20 \mathrm{~h}$. Different workup procedures were used depending on whether the product precipitated from the reaction mixture or not. Workup I: the reaction was allowed to cool to room temperature and the precipitated 
product was collected by filtration, rinsed successively with toluene and $\mathrm{Et}_{2} \mathrm{O}$, and dried under vacuum. Workup II: the reaction mixture was transferred to a flask. Then, toluene $(10 \mathrm{~mL})$ was added to precipitate the product. The flask was stored in the fridge overnight. The supernatant was removed and the precipitate rinsed with toluene. $\mathrm{Et}_{2} \mathrm{O}(10 \mathrm{~mL})$ was added and the precipitate was triturated with a spatula. The solid was collected, rinsed with $\mathrm{Et}_{2} \mathrm{O}$ and dried under vacuum.

The synthesis of compounds $7^{5}$ and $\mathbf{1 5 ^ { 4 7 , 4 8 }}$ was reported before. We report here for the first time the detailed ${ }^{1} \mathrm{H}$ and ${ }^{13} \mathrm{C}$ NMR spectroscopic data for $\mathbf{1 5 .}$

4,4'-bis((trimethylphosphonio)methyl)benzophenone dibromide (1). The reaction was carried out following the general procedure with trimethylphosphine (1M in toluene). The product was obtained as a colorless solid (82\%) following workup I procedure; mp $208-213{ }^{\circ} \mathrm{C}$ with previous softening (DMF/toluene); ${ }^{1} \mathrm{H}$ NMR (300 MHz, DMSO) $\delta 7.81(\mathrm{~d}, J=7.8,4 \mathrm{H}, \operatorname{Ar} H), 7.52(\mathrm{dd}, J=$ 8.2, 2.3, 4H, $\mathrm{ArH}), 3.97\left(\mathrm{~d}, J=17.5,4 \mathrm{H}, \mathrm{PhCH}_{2} \mathrm{P}\right), 1.86\left(\mathrm{~d}, J=14.7,18 \mathrm{H}, \mathrm{CH}_{3}\right) .{ }^{13} \mathrm{C}$ NMR $(75$ MHz, DMSO) $\delta 195.21(C O), 136.59(\mathrm{~d}, J=3.7, C q), 135.01\left(\mathrm{~d}, J=9.1, C_{q}\right), 130.77(\mathrm{~d}, J=3.2$, $C H), 130.49(\mathrm{~d}, J=5.2, \mathrm{CH}), 29.84\left(\mathrm{~d}, J=48.2, \mathrm{CH}_{2}\right), 7.43\left(\mathrm{~d}, J=54.0, \mathrm{CH}_{3}\right)$. LRMS $\left(\mathrm{ES}^{+}\right) \mathrm{m} / z$ $359.11\left[(\mathrm{M}-\mathrm{H})^{+}\right], 180.23\left[\mathrm{M}^{2+}, 100 \%\right]$. ESI-HRMS m/z $359.1696(\mathrm{M}-\mathrm{H})^{+}\left(\mathrm{C}_{21} \mathrm{H}_{29} \mathrm{OP}_{2}\right.$ requires 359.1688). HPLC $\geq 95 \%$.

4,4'-bis((triethylphosphonio)methyl)benzophenone dibromide (2). The reaction was carried out following the general procedure using dry toluene instead of DMF, and triethylphosphine (1M in THF). The yellow precipitate was collected by filtration and rinsed with toluene. Recrystallization from hot DMF afforded 2 as a yellowish solid (58\%); mp $284-288{ }^{\circ} \mathrm{C}$ with previous softening (DMF); ${ }^{1} \mathrm{H}$ NMR (300 MHz, DMSO) $\delta 7.79(\mathrm{~d}, J=8.0,4 \mathrm{H}, \operatorname{Ar} H), 7.58(\mathrm{dd}, J=8.0,2.0,4 \mathrm{H}, \operatorname{Ar} H)$, $4.02\left(\mathrm{~d}, J=16.1,4 \mathrm{H}, \mathrm{PhCH} \mathrm{H}_{2} \mathrm{P}\right), 2.26\left(\mathrm{dq}, J=15.2,7.6,12 \mathrm{H}, \mathrm{CH}_{2} \mathrm{CH}_{3}\right), 1.14(\mathrm{dt}, J=18.3,7.6,18 \mathrm{H}$, $\left.\mathrm{CH}_{3}\right) .{ }^{13} \mathrm{C}$ NMR (75 MHz, DMSO) $\delta 195.05(\mathrm{CO}), 136.54\left(\mathrm{~d}, J=3.4, C_{q}\right), 134.85\left(\mathrm{~d}, J=8.5, C_{q}\right)$, $130.76(\mathrm{~d}, J=6.7, C H), 130.68(\mathrm{~d}, J=3.9, C H), 24.92\left(\mathrm{~d}, J=44.1, \mathrm{PhCH}_{2} \mathrm{P}\right), 11.13(\mathrm{~d}, J=48.1$, 
$\left.\mathrm{CH}_{2}\right), 5.58\left(\mathrm{~d}, \mathrm{~J}=5.4, \mathrm{CH}_{3}\right)$. LRMS $\left(\mathrm{ES}^{+}\right) \mathrm{m} / z 443.25\left[(\mathrm{M}-\mathrm{H})^{+}\right], 222.32\left[\mathrm{M}^{2+}, 100 \%\right]$. ESI-HRMS $m / z$ 443.2634 $(\mathrm{M}-\mathrm{H})^{+}\left(\mathrm{C}_{27} \mathrm{H}_{41} \mathrm{OP}_{2}\right.$ requires 443.2627). HPLC $\geq 95 \%$.

4,4'-bis((tripropylphosphonio)methyl)benzophenone dibromide (3). The reaction was carried out following the general procedure using dry toluene instead of DMF, and tri- $n$-propylphosphine. The reaction was allowed to cool to room temperature whereupon a yellow sticky residue was precipitated on the walls of the tube. The supernatant was discarded and the precipitate dissolved in a little DMF. Then, 3 was obtained as a yellowish solid (61\%) following workup I procedure; mp 90-95 ${ }^{\circ} \mathrm{C}$ with previous softening (DMF/toluene); ${ }^{1} \mathrm{H}$ NMR (300 MHz, DMSO) $\delta 7.80(\mathrm{~d}, J=8.1$, 4H, $\operatorname{Ar} H), 7.57(\mathrm{dd}, J=8.1,1.9,4 \mathrm{H}, \operatorname{Ar} H), 4.01\left(\mathrm{~d}, J=16.0,4 \mathrm{H}, \mathrm{PhCH}{ }_{2} \mathrm{P}\right), 2.24-2.17(\mathrm{~m}, 12 \mathrm{H}$, $\left.\mathrm{PCH}_{2} \mathrm{CH}_{2}\right), 1.53\left(\mathrm{dp}, J=14.9,7.3,12 \mathrm{H}, \mathrm{CH}_{2} \mathrm{CH}_{3}\right), 1.01\left(\mathrm{dt}, J=7.3,1.2,18 \mathrm{H}, \mathrm{CH}_{3}\right) .{ }^{13} \mathrm{C}$ NMR $(75$ MHz, DMSO) $\delta 194.64(C O), 136.60(\mathrm{~d}, J=3.4, C q), 134.92\left(\mathrm{~d}, J=8.6, C_{q}\right), 130.74(\mathrm{~d}, J=2.8$, $C H), 130.64(\mathrm{~d}, J=5.0, C H), 25.93\left(\mathrm{~d}, J=43.9, \mathrm{PhCH}_{2} \mathrm{P}\right), 20.01\left(\mathrm{~d}, J=46.2, \mathrm{P} C H_{2}\right), 15.64(\mathrm{~d}, J=$ 16.7, $\left.\mathrm{CH}_{2}\right), 15.06\left(\mathrm{~d}, J=4.3, \mathrm{CH}_{3}\right)$. LRMS $\left(\mathrm{ES}^{+}\right) \mathrm{m} / z 527.33\left[(\mathrm{M}-\mathrm{H})^{+}\right], 264.35\left[\mathrm{M}^{2+}, 100 \%\right]$. Anal. Calcd. $\left(\mathrm{C}_{33} \mathrm{H}_{54} \mathrm{Br}_{2} \mathrm{OP}_{2} \bullet 2 \mathrm{H}_{2} \mathrm{O}\right):$ C, 54.70; H, 8.07. Found: C, 54.56; H, 7.90.

4,4'-bis((triisopropylphosphonio)methyl)benzophenone dibromide (4). The reaction was carried out following the general procedure using dry toluene instead of DMF, and tri-isopropylphosphine (technical grade 90\%). Compound 4 was obtained as a yellowish solid (59\%) following workup I procedure and recrystallization from DMF; mp $277-278{ }^{\circ} \mathrm{C}(\mathrm{DMF}) ;{ }^{1} \mathrm{H}$ NMR (300 MHz, DMSO) $\delta$ $7.78(\mathrm{~d}, J=8.1,4 \mathrm{H}, \operatorname{Ar} H), 7.61(\mathrm{dd}, J=8.1,1.7,4 \mathrm{H}, \mathrm{Ar} H), 4.20\left(\mathrm{~d}, J=14.9,4 \mathrm{H}, C_{2} \mathrm{P}\right), 3.05-$ $2.78(\mathrm{~m}, 6 \mathrm{H}, \mathrm{CH}), 1.31\left(\mathrm{dd}, J=15.9,7.2,36 \mathrm{H}, \mathrm{CH}_{3}\right) .{ }^{13} \mathrm{C} \mathrm{NMR}(75 \mathrm{MHz}, \mathrm{DMSO}) \delta 194.78(\mathrm{CO})$, $136.43\left(\mathrm{~d}, J=2.8, C_{q}\right), 135.55\left(\mathrm{~d}, J=8.0, C_{q}\right), 131.07(\mathrm{~d}, J=4.6, C H), 130.75(C H), 22.04(\mathrm{~d}, J=$ 40.4), $20.50(\mathrm{~d}, J=41.0), 16.63\left(\mathrm{~d}, J=3.2, \mathrm{CH}_{3}\right) . \mathrm{LRMS}\left(\mathrm{ES}^{+}\right) \mathrm{m} / z 527.27\left[(\mathrm{M}-\mathrm{H})^{+}\right]$. Anal. Calcd. $\left(\mathrm{C}_{33} \mathrm{H}_{54} \mathrm{Br}_{2} \mathrm{OP}_{2} \bullet 1 / 3 \mathrm{H}_{2} \mathrm{O} \bullet 1 / 3 \mathrm{C}_{3} \mathrm{H}_{7} \mathrm{NO}\right)$ : C, 56.80; H, 7.99, Br, 22.23. Found: $\mathrm{C}, 56.64 ; \mathrm{H}, 8.38 ; \mathrm{Br}$, 22.08 . 
4,4'-bis((tributylphosphonio)methyl)benzophenone dibromide (5). The reaction was carried out following the general procedure with tri-n-butylphosphine. Compound $\mathbf{5}$ was obtained as a beige solid (87\%) following workup II procedure; mp $154.2-157.7{ }^{\circ} \mathrm{C}$ with previous softening $\left(\mathrm{Et}_{2} \mathrm{O}\right) ;{ }^{1} \mathrm{H}$ NMR (300 MHz, DMSO) $\delta 7.79(\mathrm{~d}, J=7.9,4 \mathrm{H}, \operatorname{Ar} H), 7.57(\mathrm{~d}, J=7.9,4 \mathrm{H}, \operatorname{Ar} H), 4.01(\mathrm{~d}, J=16.0$, 4H, $\mathrm{PhCH} 2 \mathrm{P}$ ), 2.19 (br m, 12H, $\mathrm{PCH}_{2} \mathrm{CH}_{2}$ ), 1.41 (br m, 24H, $\left.\mathrm{CH}_{2} \mathrm{CH}_{2}\right), 0.90$ (t, $J=6.8,18 \mathrm{H}, \mathrm{CH}_{3}$ ). ${ }^{13} \mathrm{C}$ NMR (75 MHz, DMSO) $\delta 195.12(C O), 136.64\left(\mathrm{~d}, J=3.4, C_{q}\right), 134.98\left(\mathrm{~d}, J=8.4, C_{q}\right), 130.67$ (CH), $130.61(\mathrm{CH}), 25.90\left(\mathrm{~d}, \mathrm{~J}=43.8, \mathrm{PhCH}_{2} \mathrm{P}\right), 23.70\left(\mathrm{~d}, \mathrm{~J}=15.9, \mathrm{CH}_{2}\right), 22.92\left(\mathrm{~d}, J=4.5, \mathrm{CH}_{2}\right)$, $17.79\left(\mathrm{~d}, J=46.8, \mathrm{PCH}_{2}\right), 13.60\left(\mathrm{CH}_{3}\right)$. LRMS $\left(\mathrm{ES}^{+}\right) \mathrm{m} / z 611.35\left[(\mathrm{M}-\mathrm{H})^{+}\right], 306.38\left[\mathrm{M}^{2+}, 100 \%\right]$. ESI-HRMS $m / z 611.4507(\mathrm{M}-\mathrm{H})^{+}\left(\mathrm{C}_{39} \mathrm{H}_{65} \mathrm{OP}_{2}\right.$ requires 611.4505$)$. HPLC $\geq 95 \%$.

4,4'-bis((triisobutylphosphonio)methyl)benzophenone dibromide (6). The reaction was carried out following the general procedure with tri-isobutylphosphine. Compound $\mathbf{6}$ was obtained as an off-white solid (56\%) following workup II procedure; mp 79-85 ${ }^{\circ} \mathrm{C}$ (DMF/toluene); ${ }^{1} \mathrm{H}$ NMR (300 MHz, DMSO) $\delta 7.80(\mathrm{~d}, J=8.0,4 \mathrm{H}, \operatorname{Ar} H), 7.60(\mathrm{dd}, J=8.0,1.8,4 \mathrm{H}, \operatorname{Ar} H), 4.09(\mathrm{~d}, J=15.6,4 \mathrm{H}$, $\left.\mathrm{PhCH}_{2} \mathrm{P}\right), 2.26\left(\mathrm{dd}, J=13.1,6.1,12 \mathrm{H}, \mathrm{PCH}_{2} \mathrm{CH}\right), 2.12(\mathrm{~m}, J=6.1,6 \mathrm{H}, \mathrm{CH}), 1.02(\mathrm{~d}, J=6.6,36 \mathrm{H}$, $\left.\mathrm{CH}_{3}\right) .{ }^{13} \mathrm{C}$ NMR $(75 \mathrm{MHz}, \mathrm{DMSO}) \delta 195.13(\mathrm{CO}), 136.63\left(\mathrm{~d}, J=3.3, C_{q}\right), 134.91\left(\mathrm{~d}, J=8.7, C_{q}\right)$, $131.00(\mathrm{~d}, J=4.8, C H), 130.64(\mathrm{~d}, J=2.3, C H), 28.00\left(\mathrm{~d}, J=43.0, C H_{2} \mathrm{P}\right), 27.62(\mathrm{~d}, J=42.8$, $\left.\mathrm{CH}_{2} \mathrm{P}\right), 24.88\left(\mathrm{~d}, \mathrm{~J}=8.6, \mathrm{CH}_{3}\right), 23.03\left(\mathrm{~d}, J=4.6, \mathrm{CH}_{2}\right)$. LRMS $\left(\mathrm{ES}^{+}\right) \mathrm{m} / z 611.37\left[(\mathrm{M}-\mathrm{H})^{+}\right], 306.33$ $\left[\mathrm{M}^{2+}, 100 \%\right]$. ESI-HRMS $m / z 611.4514(\mathrm{M}-\mathrm{H})^{+}\left(\mathrm{C}_{39} \mathrm{H}_{65} \mathrm{OP}_{2}\right.$ requires 611.4505). HPLC $=92 \%$.

4,4'-bis((tricyclohexylphosphonio)methyl)benzophenone dibromide (8). The reaction was carried out following the general procedure with tricyclohexylphosphine. The reaction was concentrated to ca. $1 \mathrm{~mL}$ resulting a yellowish oil that was diluted with toluene $(10 \mathrm{~mL})$. Addition of $\mathrm{Et}_{2} \mathrm{O}(10 \mathrm{~mL})$ caused precipitation of an oily residue. The flask was stored in the refrigerator overnight. The supernatant was removed and the oily precipitate was rinsed with toluene. $\mathrm{Et}_{2} \mathrm{O}$ (10 $\mathrm{mL}$ ) was added to the oily precipitate which was triturated with a spatula to afford $\mathbf{8}$ as a colorless solid (75\%); mp 151-156 ${ }^{\circ} \mathrm{C}$ with previous softening (DMF/toluene/Et $\left.2 \mathrm{O}\right) ;{ }^{1} \mathrm{H}$ NMR (300 MHz, 
DMSO) $\delta 7.79(\mathrm{~d}, J=7.7,4 \mathrm{H}, \operatorname{Ar} H), 7.57(\mathrm{~d}, J=7.7,4 \mathrm{H}, \operatorname{Ar} H), 4.17\left(\mathrm{~d}, J=14.7,4 \mathrm{H}, \mathrm{PhCH}{ }_{2} \mathrm{P}\right)$, $2.58(\mathrm{~m}, 6 \mathrm{H}, \mathrm{PCH}), 2.15-1.14\left(\mathrm{~m}, 60 \mathrm{H}, \mathrm{CH}_{2}\right) .{ }^{13} \mathrm{C} \mathrm{NMR}(75 \mathrm{MHz}, \mathrm{DMSO}) \delta 195.09(\mathrm{CO}), 136.64$ $\left(C_{q}\right), 135.79\left(\mathrm{~d}, J=7.9, C_{q}\right), 131.03(\mathrm{~d}, J=4.5, C H), 130.72(C H), 29.89(\mathrm{~d}, J=39.4, \mathrm{PCH}), 26.41$ $\left(\mathrm{CH}_{2}\right), 26.24\left(\mathrm{CH}_{2}\right), 25.31\left(\mathrm{CH}_{2}\right), 21.80(\mathrm{~d}, \mathrm{~J}=39.9, \mathrm{PCH})$. LRMS $\left(\mathrm{ES}^{+}\right) \mathrm{m} / z 767.44$ [(M-H) $\left.{ }^{+}\right]$, $383.99\left[\mathrm{M}^{2+}, 100 \%\right]$. ESI-HRMS $m / z 767.5451(\mathrm{M}-\mathrm{H})^{+}\left(\mathrm{C}_{51} \mathrm{H}_{77} \mathrm{OP}_{2}\right.$ requires 767.5444$)$. HPLC $\geq$ 95\%.

4,4'-bis((trioctylphosphonio)methyl)benzophenone dibromide (9). The reaction was carried out following the general procedure with tri-n-octylphosphine (technical grade $90 \%$ ). Compound 9 was isolated as a yellowish hygroscopic solid (33\%) following the same workup as described for $\mathbf{8}$; ${ }^{1} \mathrm{H}$ NMR (300 MHz, $\left.\mathrm{CDCl}_{3}\right) \delta 7.57(\mathrm{~m}, 4 \mathrm{H}, \mathrm{ArH}), 7.45(\mathrm{~d}, J=7.6,4 \mathrm{H}, \mathrm{ArH}), 4.66(\mathrm{~d}, J=16.1,4 \mathrm{H}$, $\mathrm{PhCH}_{2} \mathrm{P}$ ), 2.31 (br m, 12H, PCH $\left.\mathrm{CH}_{2}\right), 1.7-1.1\left(\mathrm{~m}, 72 \mathrm{H},\left(\mathrm{CH}_{2}\right)_{6}\right), 0.79\left(\mathrm{t}, J=5.5,18 \mathrm{H}, \mathrm{CH}_{3}\right) .{ }^{13} \mathrm{C}$ NMR $\left(75 \mathrm{MHz}, \mathrm{CDCl}_{3}\right) \delta 194.53,136.43,134.37(\mathrm{~d}, J=9.1), 130.72,130.64,31.77,30.99(\mathrm{~d}, J=$ 14.8), $\left.29.05(\mathrm{~d}, J=6.6), 22.70,22.02(\mathrm{~d}, J=4.7), 19.71(\mathrm{~d}, J=24.1), 18.94,14.18 . \mathrm{LRMS}_{(\mathrm{ES}}{ }^{+}\right)$ $m / z 947.86\left[(\mathrm{M}-\mathrm{H})^{+}\right], 473.96\left[\mathrm{M}^{2+}, 100 \%\right]$. ESI-HRMS $m / z 473.4093(\mathrm{M}-\mathrm{H})^{2+}\left(\mathrm{C}_{63} \mathrm{H}_{112} \mathrm{OP}_{2}\right.$ requires 473.4094). HPLC $\geq 95 \%$.

4,4'-bis((dimethylphenylphosphonio)methyl)benzophenone dibromide (10). The reaction was carried out following the general procedure with dimethylphenylphosphine. Compound $\mathbf{1 0}$ was obtained as an off-white solid (79\%) following workup II procedure; mp 95-100 ${ }^{\circ} \mathrm{C}$ (decomp.); ${ }^{1} \mathrm{H}$ NMR (300 MHz, DMSO) $\delta 8.05-7.89(\mathrm{~m}, 4 \mathrm{H}, \operatorname{Ar} H), 7.82(\mathrm{dd}, J=7.6,5.7,2 \mathrm{H}, \operatorname{Ar} H), 7.76-7.61$ (m, 8H, ArH), $7.31(\mathrm{dd}, J=8.3,2.4,4 \mathrm{H}, \operatorname{Ar} H), 4.25\left(\mathrm{~d}, J=17.0,4 \mathrm{H}, \mathrm{PhCH}_{2} \mathrm{P}\right), 2.25(\mathrm{~d}, J=14.5$, 12H, $\left.\mathrm{CH}_{3}\right) .{ }^{13} \mathrm{C}$ NMR $(75 \mathrm{MHz}, \mathrm{DMSO}) \delta 195.15(\mathrm{CO}), 136.56\left(\mathrm{~d}, J=3.9, C_{q}\right), 134.62(\mathrm{~d}, J=2.6$, $\left.C_{q}\right), 134.51(\mathrm{~d}, J=9.1), 132.31(\mathrm{~d}, J=10.0, C H), 130.58(\mathrm{~m}, C H), 129.79(\mathrm{~d}, J=12.4, C H), 120.75$ $\left(\mathrm{d}, J=84.2, C_{q}\right), 30.83\left(\mathrm{~d}, J=46.5, \mathrm{CH}_{3}\right), 6.42\left(\mathrm{~d}, J=54.5, \mathrm{CH}_{3}\right)$. LRMS $\left(\mathrm{ES}^{+}\right) \mathrm{m} / z 483.13$ [(M$\left.\mathrm{H})^{+}\right], 242.23\left[\mathrm{M}^{2+}, 100 \%\right]$. ESI-HRMS $m / z 483.2000(\mathrm{M}-\mathrm{H})^{+}\left(\mathrm{C}_{31} \mathrm{H}_{33} \mathrm{OP}_{2}\right.$ requires 483.2001). HPLC $=94 \%$. 
4,4'-bis((diethylphenylphosphonio)methyl)benzophenone dibromide (11). The reaction was carried out following the general procedure with diethylphenylphosphine. Compound 11 was obtained as an off-white solid (60\%) following workup II procedure; mp $69-76^{\circ} \mathrm{C}$ (DMF/toluene); ${ }^{1} \mathrm{H}$ NMR (300 MHz, DMSO) $\delta 8.04-7.78(\mathrm{~m}, 6 \mathrm{H}, \mathrm{Ar} H), 7.72(\mathrm{dt}, J=7.4,3.7,4 \mathrm{H}, \mathrm{Ar} H), 7.64(\mathrm{~d}, J$ $=8.0,4 \mathrm{H}, \operatorname{Ar} H), 7.29(\mathrm{dd}, J=8.2,2.1,4 \mathrm{H}, \operatorname{Ar} H), 4.37\left(\mathrm{~d}, J=16.0,4 \mathrm{H}, \mathrm{PhCH}_{2} \mathrm{P}\right), 2.81-2.59(\mathrm{~m}$, $\left.8 \mathrm{H}, \mathrm{CH}_{2} \mathrm{CH}_{3}\right), 1.16\left(\mathrm{dt}, J=19.2,7.5,12 \mathrm{H}, \mathrm{CH}_{3}\right) .{ }^{13} \mathrm{C}$ NMR $(75 \mathrm{MHz}, \mathrm{DMSO}) \delta 195.01(\mathrm{CO})$, $136.51\left(\mathrm{~d}, J=3.6, C_{q}\right), 134.88\left(\mathrm{~d}, J=2.6, C_{q}\right), 134.27(\mathrm{~d}, J=8.5), 132.99(\mathrm{~d}, J=8.7), 130.60(\mathrm{~d}, J$ $=5.6, C H), 130.52(C H), 130.13(\mathrm{~d}, J=11.7, C H), 117.22\left(\mathrm{~d}, J=79.4 ; C_{q}\right), 26.74(\mathrm{~d}, J=44.7$, $\left.\mathrm{CH}_{2} \mathrm{P}\right), 11.55\left(\mathrm{~d}, \mathrm{~J}=49.3, \mathrm{CH}_{2} \mathrm{P}\right), 5.76\left(\mathrm{~d}, J=5.0, \mathrm{CH}_{3}\right)$. LRMS $\left(\mathrm{ES}^{+}\right) \mathrm{m} / z 539.2\left[(\mathrm{M}-\mathrm{H})^{+}\right], 270.29$ $\left[\mathrm{M}^{2+}, 100 \%\right]$. ESI-HRMS $m / z$ 539.2635 $(\mathrm{M}-\mathrm{H})^{+}\left(\mathrm{C}_{35} \mathrm{H}_{41} \mathrm{OP}_{2}\right.$ requires 539.2627). HPLC $=92 \%$.

4,4'-bis((dicyclohexylphenylphosphonio)methyl)benzophenone dibromide (12). The reaction was carried out following the general procedure with dicyclohexylphenylphosphine. Workup II procedure followed by recrystallization from $\mathrm{EtOH} / \mathrm{Et}_{2} \mathrm{O}$ afforded $\mathbf{1 2}$ as a yellowish solid (33\%); $\mathrm{mp}>300{ }^{\circ} \mathrm{C}$ (decomp.); ${ }^{1} \mathrm{H} \mathrm{NMR}\left(400 \mathrm{MHz} \mathrm{CDCl}_{3}\right) \delta 8.10(\mathrm{t}, J=8.7,4 \mathrm{H}, \mathrm{Ar} H), 7.67(\mathrm{~m}, 6 \mathrm{H}$, $\operatorname{ArH}), 7.12$ (brs, 8H, ArH), 5.33 (d, $\left.J=15.2,4 \mathrm{H}, \mathrm{PhCH}{ }_{2} \mathrm{P}\right), 3.09$ (m, 4H, PCH), 2.25 - 1.00 (m, 40H, $\left.\mathrm{CH}_{2}\right) .{ }^{13} \mathrm{C}$ NMR $\left(101 \mathrm{MHz}, \mathrm{CDCl}_{3}\right) \delta 194.27(\mathrm{CO}), 135.70(\mathrm{~d}, J=3.2), 135.12(\mathrm{~d}, J=8.7)$, $134.32(\mathrm{~d}, J=2.3), 134.18(\mathrm{~d}, J=7.6), 130.83(\mathrm{~d}, J=4.8), 130.24,130.10(\mathrm{~d}, J=5.9), 115.35(\mathrm{~d}, J$ $\left.\left.=73.7, C_{q}\right), 31.28\left(\mathrm{~d}, J=42.3, \mathrm{PCH}_{2}\right), 26.73,26.55,25.74,24.82\left(\mathrm{~d}, J=40.7, \mathrm{PCH}_{2}\right) . \mathrm{LRMS}_{(\mathrm{ES}}{ }^{+}\right)$ $m / z 755.36\left[(\mathrm{M}-\mathrm{H})^{+}\right], 378.21\left[\mathrm{M}^{2+}, 100 \%\right]$. ESI-HRMS $m / z 755.4508(\mathrm{M}-\mathrm{H})^{+}\left(\mathrm{C}_{51} \mathrm{H}_{65} \mathrm{OP}_{2}\right.$ requires 755.4505). HPLC $\geq 95 \%$.

4,4'-bis((diphenylmethylphosphonio)methyl)benzophenone dibromide (13). The reaction was carried out following the general procedure with methyldiphenylphosphine. Compound $\mathbf{1 3}$ was obtained as an off-white solid (71\%) following workup II procedure; mp $110-113{ }^{\circ} \mathrm{C}(\mathrm{decomp}) ;{ }^{1} \mathrm{H}$ NMR (300 MHz, DMSO) $\delta 7.97(\mathrm{dd}, J=12.8,7.3,8 \mathrm{H}, \mathrm{Ar} H), 7.86(\mathrm{dd}, J=8.0,6.2,4 \mathrm{H}, \mathrm{Ar} H), 7.74$ $(\mathrm{td}, J=7.6,3.4,8 \mathrm{H}, \operatorname{Ar} H), 7.61(\mathrm{~d}, J=7.9,4 \mathrm{H}, \operatorname{Ar} H), 7.38-7.26(\mathrm{~m}, 4 \mathrm{H}, \operatorname{Ar} H), 4.82(\mathrm{~d}, J=16.9$, 
$\left.4 \mathrm{H}, \mathrm{PhCH} \mathrm{H}_{2} \mathrm{P}\right), 2.63\left(\mathrm{~d}, J=14.1,6 \mathrm{H}, \mathrm{CH}_{3}\right) ;{ }^{13} \mathrm{C} \mathrm{NMR}(75 \mathrm{MHz}, \mathrm{DMSO}) \delta 195.03(\mathrm{CO}), 136.60(\mathrm{~d}, J$ $=3.8), 135.02(\mathrm{~d}, J=2.5), 133.85(\mathrm{~d}, J=8.3), 133.06(\mathrm{~d}, J=10.1, C H), 130.93(\mathrm{~d}, J=5.3), 130.43$ $(\mathrm{d}, J=3.0), 130.16(\mathrm{~d}, J=12.4, C H), 120.07\left(\mathrm{~d}, J=84.6, C_{q}\right), 29.05\left(\mathrm{~d}, J=47.4, \mathrm{P} C H_{2}\right), 4.86(\mathrm{~d}, J$ $\left.\left.=55.6, \mathrm{CH}_{3}\right)\right)$. LRMS $\left(\mathrm{ES}^{+}\right) \mathrm{m} / z 607.13\left[(\mathrm{M}-\mathrm{H})^{+}\right]$. Anal. Calcd. $\left(\mathrm{C}_{41} \mathrm{H}_{38} \mathrm{Br}_{2} \mathrm{OP}_{2} \bullet 2 \mathrm{C}_{3} \mathrm{H}_{7} \mathrm{NO}\right): \mathrm{C}$, 62.79; H, 5.39, Br, 18.99. Found: C, 62.70; H, 5.83; Br, 18.74. HPLC $\geq 95 \%$.

4,4'-bis((diphenylethylphosphonio)methyl)benzophenone dibromide (14). The reaction was carried out following the general procedure with ethyldiphenylphosphine. Compound $\mathbf{1 4}$ was obtained as an off-white solid (67\%) following workup II procedure; mp $118-123{ }^{\circ} \mathrm{C}$ with previous softening (DMF/toluene); ${ }^{1} \mathrm{H}$ NMR (300 MHz, DMSO) $\delta 8.05-7.65(\mathrm{~m}, 20 \mathrm{H}, \mathrm{Ar} H), 7.54(\mathrm{~d}, J=$ 7.8, 4H, $\mathrm{ArH}), 7.17(\mathrm{~m}, 4 \mathrm{H}, \mathrm{ArH}), 4.90\left(\mathrm{~d}, J=16.2,4 \mathrm{H}, \mathrm{PhCH}_{2} \mathrm{P}\right), 3.02\left(\mathrm{~m}, 4 \mathrm{H}, \mathrm{PCH}_{2} \mathrm{CH}_{3}\right), 1.14$ $\left(\mathrm{td}, J=7.4,21,6 \mathrm{H}, \mathrm{CH}_{3}\right) .{ }^{13} \mathrm{C} \mathrm{NMR}(75 \mathrm{MHz}, \mathrm{DMSO}) \delta 195.01(\mathrm{CO}), 136.56(\mathrm{~d}, J=3.7), 135.20$ $(\mathrm{d}, J=2.1), 133.77(\mathrm{~d}, J=9.5, C H), 130.76(\mathrm{~d}, J=5.2), 130.34(C H), 130.18(C H), 117.91(\mathrm{~d}, J=$ 82.7, $\left.C_{q}\right), 27.11\left(\mathrm{~d}, J=45.7, \mathrm{PCH}_{2}\right), 12.64\left(\mathrm{~d}, J=50.6, \mathrm{PCH}_{2}\right), 5.97\left(\mathrm{~d}, J=4.7, C_{3}\right)$. LRMS $\left(\mathrm{ES}^{+}\right)$ $m / z 635.18\left[(\mathrm{M}-\mathrm{H})^{+}\right], 318.26\left[\mathrm{M}^{2+}, 100 \%\right]$. ESI-HRMS $m / z 635.2628(\mathrm{M}-\mathrm{H})^{+}\left(\mathrm{C}_{43} \mathrm{H}_{41} \mathrm{OP}_{2}\right.$ requires 635.2627). HPLC $=92 \%$.

4,4'-bis((triphenylphosphonio)methyl)benzophenone dibromide (15). ${ }^{47,48}$ The reaction was carried out following the general procedure with triphenylphosphine. Compound $\mathbf{1 5}$ was obtained as an off-white solid (66\%) following workup II procedure; mp $>200{ }^{\circ} \mathrm{C}$ (decomp.); ${ }^{1} \mathrm{H}$ NMR $(300$ MHz, DMSO) $\delta 8.30-7.61(\mathrm{~m}, 30 \mathrm{H}, \operatorname{Ar} H), 7.52(\mathrm{~d}, J=7.8,4 \mathrm{H}, \operatorname{Ar} H), 7.14(\mathrm{~d}, J=7.7,4 \mathrm{H}, \operatorname{Ar} H)$, $5.33\left(\mathrm{~d}, J=16.1,4 \mathrm{H}, \mathrm{CH}_{2}\right) .{ }^{13} \mathrm{C} \mathrm{NMR}(75 \mathrm{MHz}, \mathrm{DMSO}) \delta 195.08(C O), 136.81\left(\mathrm{~d}, J=3.7, C_{q}\right)$, $135.60,134.44(\mathrm{~d}, J=10.0), 133.47(\mathrm{~d}, J=8.4), 131.33(\mathrm{~d}, J=4.9), 130.56(\mathrm{~d}, J=12.5), 130.27(\mathrm{~d}$, $J=2.7), 117.93\left(\mathrm{~d}, J=85.9, C_{q}\right), 28.43\left(\mathrm{~d}, J=46.1, C H_{2}\right) . \mathrm{LRMS}_{\left(\mathrm{ES}^{+}\right)} \mathrm{m} / z 731.21\left[(\mathrm{M}-\mathrm{H})^{+}\right], 366.3$ $\left[\mathrm{M}^{2+}, 100 \%\right]$. HPLC $\geq 95 \%$.

4,4'-bis((diphenyl-2-pyridylphosphonio)methyl)benzophenone dibromide (16). The reaction was carried out following the general procedure with diphenyl-2-pyridylphosphine. Compound $\mathbf{1 6}$ 
was obtained as a beige solid (69\%) following workup II procedure; mp $175-178{ }^{\circ} \mathrm{C}(\mathrm{decomp}.) ;{ }^{1} \mathrm{H}$ NMR (300 MHz, DMSO) $\delta 9.03\left(\mathrm{~d}, J=4.5,2 \mathrm{H}, \mathrm{ArH}, 6-H_{\mathrm{pyr}}\right), 8.21(\mathrm{dt}, J=7.8,6.1,2 \mathrm{H}, \mathrm{Ar} H), 8.13$ - $7.98(\mathrm{~m}, 2 \mathrm{H}, \operatorname{Ar} H), 7.92(\mathrm{dd}, J=14.6,6.1,6 \mathrm{H}, \operatorname{Ar} H), 7.83-7.64(\mathrm{~m}, 16 \mathrm{H}, \operatorname{Ar} H), 7.46(\mathrm{~d}, J=7.9$, 4H, $\operatorname{Ar} H), 7.20-7.04(\mathrm{~m}, 4 \mathrm{H}, \operatorname{Ar} H), 5.29\left(\mathrm{~d}, J=16.4,4 \mathrm{H}, \mathrm{CH}_{2}\right) .{ }^{13} \mathrm{C}$ NMR $(75 \mathrm{MHz}, \mathrm{DMSO}) \delta$ $195.01(C O), 152.44(\mathrm{~d}, J=19.5), 144.04\left(\mathrm{~d}, J=116.4, C_{q}\right), 138.84(\mathrm{~d}, J=9.9), 136.65(\mathrm{~d}, J=3.7)$, $135.61(\mathrm{~d}, J=2.7), 134.62(\mathrm{~d}, J=9.8, C H), 133.46(\mathrm{~d}, J=8.4), 132.17(\mathrm{~d}, J=23.8), 131.30(\mathrm{~d}, J=$ 5.5), $130.43(\mathrm{~d}, J=12.5, C H), 130.12(\mathrm{~d}, J=2.7), 128.99(\mathrm{~d}, J=3.2), 117.26\left(\mathrm{~d}, J=84.9, C_{q}\right)$,

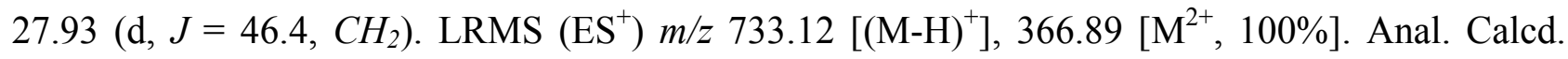
$\left(\mathrm{C}_{49} \mathrm{H}_{40} \mathrm{Br}_{2} \mathrm{~N}_{2} \mathrm{OP}_{2}\right): \mathrm{C}, 65.79 ; \mathrm{H}, 4.51, \mathrm{~N}, 3.13$. Found: C, 65.98; H, 4.80; N, 3.20.

4,4'-bis((diphenyl-o-tolylphosphonio)methyl)benzophenone dibromide (17). The reaction was carried out following the general procedure with diphenyl(o-tolyl)phosphine. Compound 17 was obtained as an off-white solid (55\%) following workup II procedure; mp 255.9-262.7 ${ }^{\circ} \mathrm{C}$ with previous softening (DMF/toluene); ${ }^{1} \mathrm{H} \mathrm{NMR}\left(300 \mathrm{MHz}, \mathrm{CDCl}_{3}\right) \delta 8.17$ (br, 2H, ArH), $7.9-7.45$ (m, 26H, ArH), $7.22(\mathrm{~m}, 8 \mathrm{H}, \mathrm{Ar} H), 5.60\left(\mathrm{~d}, J=15.0,4 \mathrm{H}, \mathrm{CH}_{2}\right), 1.99\left(\mathrm{~s}, 6 \mathrm{H}, \mathrm{CH}_{3}\right) .{ }^{13} \mathrm{C} \mathrm{NMR}(75$ $\left.\mathrm{MHz}, \mathrm{CDCl}_{3}\right) \delta 195.58(C O), 143.50(\mathrm{~d}, J=8.4), 137.01(\mathrm{~d}, J=3.7), 136.81(\mathrm{~d}, J=10.9), 136.0(\mathrm{~d}$, $J=2.2), 135.45(\mathrm{~d}, J=2.4), 134.53(\mathrm{~d}, J=9.8), 133.82(\mathrm{~d}, J=11.0), 133.19(\mathrm{~d}, J=8.2), 132.14(\mathrm{~d}$, $J=5.4), 130.75(\mathrm{~d}, J=12.6), 130.53(\mathrm{~d}, J=2.4), 128.65,117.93\left(\mathrm{~d}, J=84.7, C_{q}\right), 116.55(\mathrm{~d}, J=$ 83.2, $C_{q}$ ), $32.24\left(\mathrm{~d}, J=47.6, \mathrm{CH}_{2}\right), 23.29\left(\mathrm{~d}, J=4.4, \mathrm{CH}_{3}\right)$. LRMS $\left(\mathrm{ES}^{+}\right) \mathrm{m} / z 759.35\left[(\mathrm{M}-\mathrm{H})^{+}\right]$, $380.1\left[\mathrm{M}^{2+}, 100 \%\right]$. ESI-HRMS $m / z 759.2936(\mathrm{M}-\mathrm{H})^{+}\left(\mathrm{C}_{53} \mathrm{H}_{45} \mathrm{OP}_{2}\right.$ requires 759.2940$)$. HPLC $=$ $92 \%$.

4,4'-bis((diphenyl-p-tolylphosphonio)methyl)benzophenone dibromide (18). The reaction was carried out following the general procedure with diphenyl(p-tolyl)phosphine. Compound $\mathbf{1 8}$ was obtained as an off-white solid (50\%) following workup II procedure; mp 296.9-298.5 ${ }^{\circ} \mathrm{C}$ (DMF/toluene); ${ }^{1} \mathrm{H}$ NMR (300 MHz, $\left.\mathrm{CDCl}_{3}\right) \delta 8.0-7.0(\mathrm{~m}, 36 \mathrm{H}, \mathrm{ArH}), 5.73$ (br, 4H, $\left.\mathrm{CH}_{2}\right), 2.44$ (s, $\left.6 \mathrm{H}, \mathrm{CH}_{3}\right) .{ }^{13} \mathrm{C} \mathrm{NMR}\left(75 \mathrm{MHz}, \mathrm{CDCl}_{3}\right) \delta 194.92(\mathrm{CO}), 146.47(\mathrm{~d}, J=2.5), 135.0$ (br), 134.86, 
$134.68(\mathrm{~d}, J=10.2, C H), 133.13(\mathrm{~d}, J=8.5), 132.29(\mathrm{~d}, J=5.0), 131.23(\mathrm{~d}, J=13.0), 130.36(\mathrm{~d}, J$ $=12.5, C H), 118.29\left(\mathrm{~d}, J=86.0, C_{q}\right), 114.08\left(\mathrm{~d}, J=88.4, C_{q}\right), 31.24\left(\mathrm{~d}, J=46.1, C H_{2}\right), 22.22$ $\left(\mathrm{CH}_{3}\right)$. LRMS $\left(\mathrm{ES}^{+}\right) \mathrm{m} / z$ 759.21 [(M-H) $\left.{ }^{+}\right], 380.24$ [M $\left.^{2+}, 100 \%\right]$. ESI-HRMS $m / z$ 759.2929 (M-H) ${ }^{+}$ $\left(\mathrm{C}_{53} \mathrm{H}_{45} \mathrm{OP}_{2}\right.$ requires 759.2940$)$. HPLC $\geq 95 \%$.

4,4'-bis((tri-2-furanylphosphonio)methyl)benzophenone dibromide (19). The reaction was carried out following the general procedure with tri-2-furylphosphine. Compound $\mathbf{1 9}$ was obtained as a beige solid (76\%) following workup II procedure; $\mathrm{mp} 214.5-223.7^{\circ} \mathrm{C}$ with previous softening (DMF/toluene); ${ }^{1} \mathrm{H}$ NMR (300 MHz, $\mathrm{CDCl}_{3}$ ) $\delta 8.03$ (br m, 14H, ArH), 7.43 (m, 6H, ArH), 6.78 (br s, 6H, ArH, 4- $\left.H_{\text {furanyl }}\right), 5.55$ (br m, 4H, $\left.\left.\mathrm{CH}_{2}\right) .{ }^{13} \mathrm{C} \mathrm{NMR} \mathrm{(75} \mathrm{MHz,} \mathrm{CDCl}_{3}\right) \delta 195.21(\mathrm{CO}), 154.06$ (d, $J=8.6, C H), 137.14\left(\mathrm{~d}, J=4.3, C_{q}\right), 133.33(\mathrm{~d}, J=22.0, C H), 131.86(\mathrm{~d}, J=6.3, C H), 131.28(\mathrm{~d}, J$ $\left.=9.9, C_{q}\right), 131.05(\mathrm{~d}, J=11.9, \mathrm{CH}), 130.1\left(\mathrm{~d}, J=125.2, C_{q}\right), 114.26(\mathrm{~d}, J=10.0, C H), 32.54(\mathrm{~d}, J=$ 53.4, $\left.\mathrm{CH}_{2}\right)$. LRMS $\left(\mathrm{ES}^{+}\right) \mathrm{m} / z 671.08\left[(\mathrm{M}-\mathrm{H})^{+}\right], 336.0\left[\mathrm{M}^{2+}, 100 \%\right]$. ESI-HRMS $m / z 671.1379(\mathrm{M}-$ $\mathrm{H})^{+}\left(\mathrm{C}_{39} \mathrm{H}_{29} \mathrm{O}_{7} \mathrm{P}_{2}\right.$ requires 671.1383). HPLC $\geq 95 \%$.

Cultured Cells. Promastigotes from the Leishmania donovani strain MHOM/SD/00/1S-2D, its derived isogenic strain, 3-Luc, which expresses a C-terminal mutated form of luciferase (cytoplasmic luciferase), and L. pifanoi axenic amastigotes (MHOM/VE/60/Ltrod) were grown as described. ${ }^{29,49}$

Peritoneal macrophages from BALB/c mice were obtained by previous elicitation of the mouse by a single intraperitoneal injection of $1 \mathrm{~mL}$ of $3 \%$ sodium thioglycolate, four days priors to macrophage harvesting by peritoneal lavage.

Unless otherwise stated, reagents were purchased from Sigma-España (Madrid, Spain). Propidium iodide, SYTOX Green, rhodamine 123 [2-(6-Amino-3-imino-3H-xanthen-9-yl)benzoic acid methyl ester, chloride] and DMNPE-luciferin [D-luciferin, 1-(4, 5-dimethoxy-2-nitrophenyl) ethyl ester] were purchase from Invitrogen (Barcelona, Spain). 
Fluorescence and luminescence measurements were recorded in a Polarstar Galaxy microplate reader (BMG Labotechnologies, Offenburg, Germany), fitted with the corresponding optical setting, unless otherwise stated.

Cytotoxic Activity Measurements. Promastigotes and amastigotes were harvested at late exponential phase, washed twice in Hanks' buffer, supplemented with $10 \mathrm{mM}$ D-glucose (pH 7.2) (HBSS-Glc) at $4{ }^{\circ} \mathrm{C}$, and resuspended in the same buffer at $2 \times 10^{7}$ cells $/ \mathrm{mL}$. These standard conditions were maintained for the rest of the experiments unless otherwise stated. Aliquots (120 $\mu \mathrm{L}$ ) of this cellular suspension were incubated with the drugs for $4 \mathrm{~h}$, either at $25^{\circ} \mathrm{C}$ or $32{ }^{\circ} \mathrm{C}$ for promastigotes and amastigotes, respectively. Afterwards, $20 \mu \mathrm{L}$ aliquots of this suspension were taken, added to $1 \mathrm{~mL}$ HBSS-Glc and centrifuged to remove unbound reagent. Washed parasites were resuspended in $100 \mu \mathrm{L}$ of their respective growth medium devoid of phenol red, transferred into a new 96-well microplate, and allowed to proliferate $\left(48 \mathrm{~h}, 25^{\circ} \mathrm{C}\right.$ for promastigotes; $96 \mathrm{~h}, 32{ }^{\circ} \mathrm{C}$ for amastigotes). Finally, $100 \mu \mathrm{L}$ of MTT solution $(1 \mathrm{mg} / \mathrm{mL})$ in HBSS-Glc were added, and substrate reduction allowed to proceed for $2 \mathrm{~h}$ at $25^{\circ} \mathrm{C}$ or $32{ }^{\circ} \mathrm{C}$ for promastigotes or amastigotes, respectively. Precipitated formazan was solubilized by addition of $100 \mu \mathrm{L}$ of $10 \%(\mathrm{w} / \mathrm{v})$ SDS solution and read in a 450 Bio-Rad ELISA microplate reader equipped with a $600 \mathrm{~nm}$ filter. ${ }^{29}$ To measure the short-term effect, $100 \mu \mathrm{L}\left(1.6 \times 10^{6}\right.$ promastigotes $)$ of the remaining parasites, were washed with $1 \mathrm{~mL}$ HBSS-Glc, resuspended and assayed for MTT reduction as above.

The induction of apoptosis by 7 was monitored by analysis of the sub- $\mathrm{G}_{1}$ peak in parasites incubated overnight with different concentrations of 7. After the incubation, parasites were stained with $50 \mu \mathrm{g} / \mathrm{mL}$ propidium iodide (PI) and individual cellular fluorescence measured in a Beckman Coulter FC500 MPL cytofluorometer. As positive control for apoptosis induction, parasites were treated in identical conditions with $15 \mu \mathrm{M}$ miltefosine (hexadecylphosphocholine). ${ }^{31}$

$\mathrm{BALB} / \mathrm{c}$ peritoneal macrophages were resuspended in their culture medium at a final density of $10^{6}$ cells $/ \mathrm{mL}$, plated in a 96 -well culture microplate $(100 \mu \mathrm{L} /$ well $)$, and incubated with compound 
7 for $24 \mathrm{~h}$ at $37^{\circ} \mathrm{C}$. Cytotoxicity was assessed using the colorimetric MTT reduction assay and expressed as the percentage of the value obtained for control cells.

Changes in Intracellular ATP Levels. The in vivo variation of intracellular ATP levels in L. donovani promastigotes was measured in 3-Luc parasites expressing a cytoplasmic form of Photinus pyralis luciferase. ${ }^{29}$ Briefly, the substrate for luciferase, DMNPE-luciferin [D-luciferin, 1(4, 5-dimethoxy-2-nitrophenyl) ethyl ester], was prepared as a $5 \mathrm{mM}$ stock solution in DMSO. It was added to the 3 -Luc promastigote suspension $\left(2 \times 10^{7}\right.$ cells $\left./ \mathrm{mL}\right)$ in HBSS-Glc at a final concentration of $25 \mu \mathrm{M}$, and aliquots of this suspension were immediately distributed into a 96-well microplate $(100 \mu \mathrm{L} /$ well). Compound 7 was added once the luminescence reached a plateau. This point was considered as time zero, and its luminescence taken as $100 \%$. Changes in luminescence were recorded for $80 \mathrm{~min}$ using a luminescence optics setting. The measurements were averaged every 4 s. In vitro inhibition of luciferase (EC 1.13.12.7) by the compound was tested as described ${ }^{29}$ using a commercial purified enzyme (Roche Applied Sciences, Madrid, Spain).

Plasma Membrane Permeabilization. It was assessed by the entrance of the vital dye SYTOX green (MW 600), according to the procedure described previously. ${ }^{50}$ Briefly, compound 7 was added to L. donovani promastigotes in HBSS-Glc $\left(2 \times 10^{7}\right.$ promastigotes $\left./ \mathrm{mL}\right)$ preincubated with $1 \mu \mathrm{M}$ SYTOX green. Entrance of the dye into the intracellular compartment is only afforded through injured membranes, with lesions large enough to allow dye passage. The increase of fluorescence, due to binding of the dye to intracellular nucleic acids, was monitored using 485 and $520 \mathrm{~nm}$ filters for excitation and emission wavelengths, respectively. Full permeation was considered as that achieved by $0.1 \%$ Triton X-100 (TX-100).

Electron Microscopy. Promastigotes were incubated with compound 7 according to the standard procedure, washed twice in PBS, and fixed in 5\%(w/v) glutaraldehyde in the same medium. Afterwards, parasites were included with $2.5 \%(\mathrm{w} / \mathrm{v}) \mathrm{OsO}_{4}$ for $1 \mathrm{~h}$, gradually dehydrated 
in ethanol $(30,50,70,90$ and 100\% (v/v); $30 \mathrm{~min}$ each), and propylene oxide $(1 \mathrm{~h})$, embedded in Epon 812 resin, and observed in a Jeol-1230 electron microscope as described. ${ }^{50}$

Effects on Mitochondrial Activity. Variation of the mitochondrial membrane potential $\left(\Delta \Psi_{\mathrm{m}}\right)$ of promastigotes was measured by rhodamine 123 accumulation. ${ }^{39}$ To this end, promastigotes were incubated in their growth medium with the leishmanicidal benzophenonederived bisphosphonium compounds at their respective $\mathrm{LC}_{50}$ overnight, and dye incorporation measured in a Beckman Coulter FC500 MPL cytofluorometer (excitation and emission wavelengths 488 and $525 \mathrm{~nm}$, respectively). Parasites either untreated, or fully depolarized by incubation with 1 $\mathrm{mM} \mathrm{KCN}$, were used as controls. Following the same protocol, a more extensive range of concentrations was used to study the effect of compound 7 on rhodamine 123 accumulation.

Oxygen consumption rates were measured in a Clark-oxygen electrode (Hansatech, KingsLynn, UK) at $25{ }^{\circ} \mathrm{C}$, using $1 \mathrm{~mL}$ of a promastigote suspension $\left(10^{8}\right.$ cells $\left./ \mathrm{mL}\right)$ in respiration buffer supplemented with $5 \mathrm{mM}$ succinate and $1 \mathrm{mg} / \mathrm{mL}$ fatty acid free BSA as described. ${ }^{37}$ Cells were permeabilized with $60 \mu \mathrm{M}$ digitonin, which allows a selective permeation of the plasma membrane but not of the inner mitochondrial membrane. ${ }^{51}$ Afterwards, $100 \mu \mathrm{M}$ ADP was added to restore state 3 of respiration, and once a steady rate was reached, compound 7 was added, followed by a selective set of substrates and inhibitors specific for the different complexes of the respiratory chain, at concentrations stated in the corresponding figures.

Statistical Analysis. Data represent the mean of triplicate samples \pm S.D. $\mathrm{LC}_{50}$ values were calculated from the sigmoidal inhibition curves using the SigmaPlot 11.0 software.

Acknowledgments. This work was supported by grants from the Spanish Ministerio de Educación y Ciencia to C.D. (SAF2006-04698) and to L.R. (PET2006-0139-01), Fondo de Investigaciones Sanitarias (PI061125, PS09/0192, and RD 06/0021/0006) and regional government of Madrid (SBIO-0260/2006) to L.R.. P.R. is recipient of a Studienstiftung des deutschen Volkes fellowship. We 
gratefully acknowledge Dr. H. de Koning for his comments and suggestions on the manuscript, and the IQM Mass Spectrometry Service Centre for HPLC-MS analysis. 


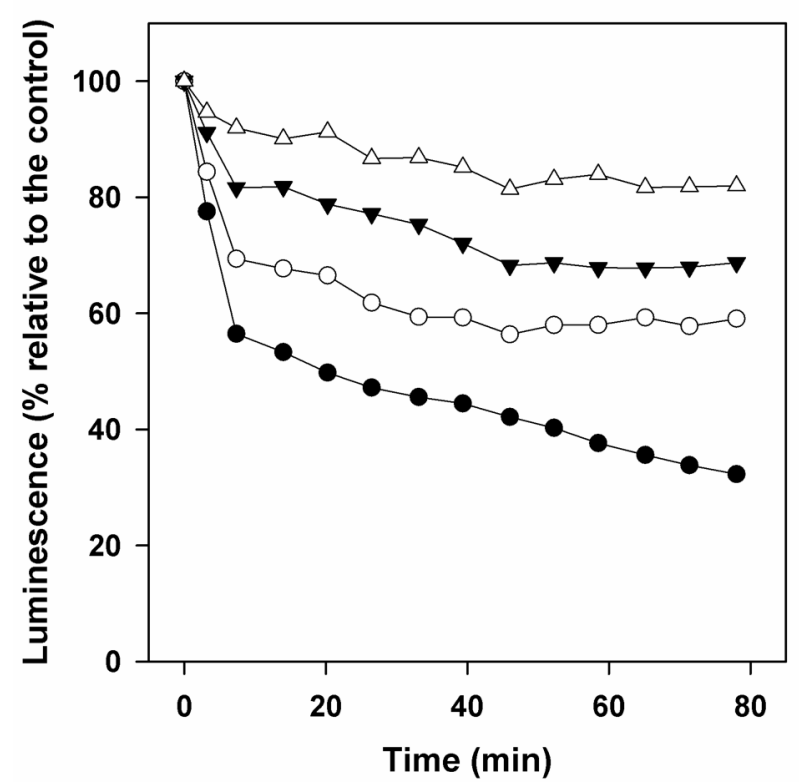

Figure 1. Variation of intracellular ATP level assessed by in vivo luminescence of 3-Luc promastigotes after addition of compound 7. Promastigotes $\left(2 \times 10^{7}\right.$ cells $\left./ \mathrm{mL}\right)$ were preloaded with $25 \mu \mathrm{M}$ DMNPE-luciferin; when luminescence signal reached a plateau luminescence was considered as $100 \%$ and compound 7 was added $(t=0)$. Variation in luminescence was normalized relative to the control untreated parasites. Compound 7 concentrations $(\mu \mathrm{M}): 0.6(\triangle), 1.0(\boldsymbol{\nabla}), 2.5$ (○), $8.0(\bigcirc)$. 

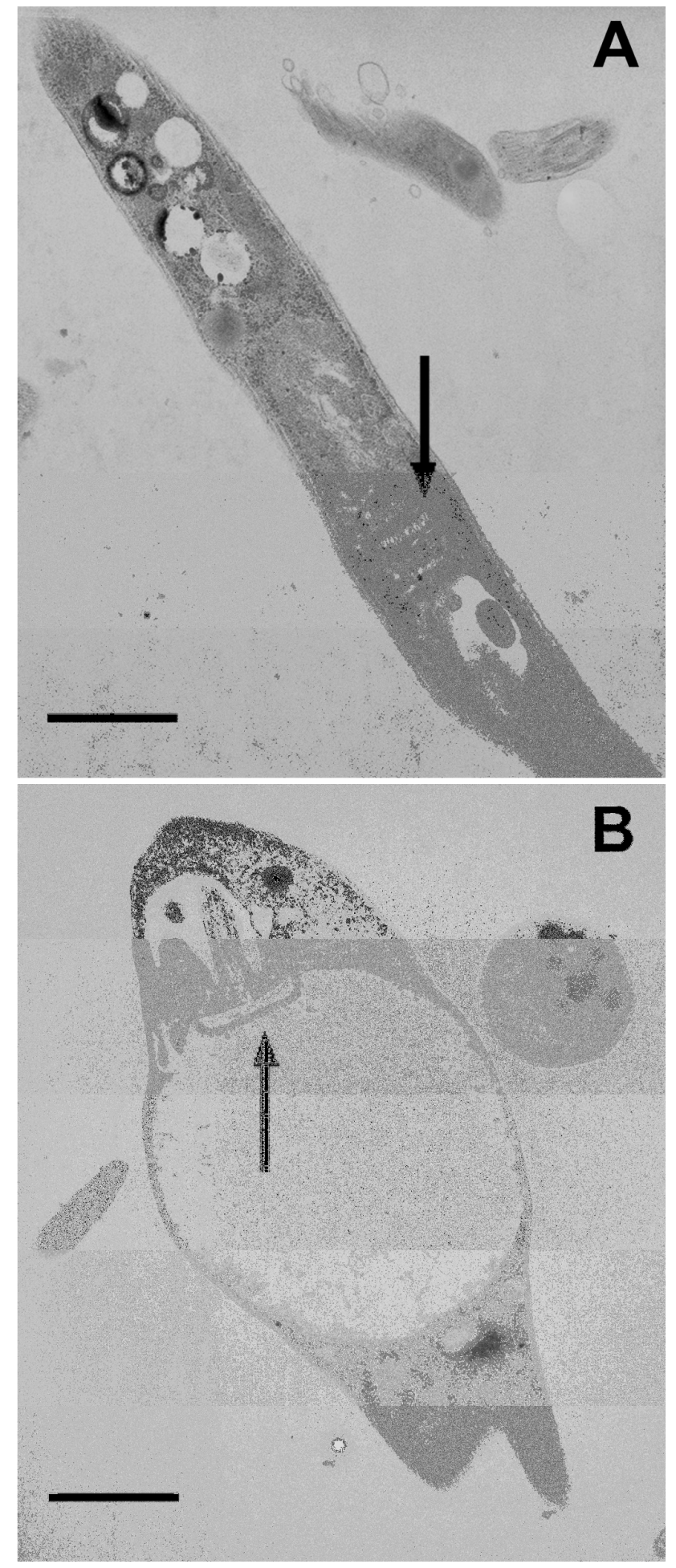

Figure 2. Electron microscopy of $L$. donovani promastigotes treated with compound 7. (A) Control parasites. (B) Parasites were incubated for $4 \mathrm{~h}$ with $5 \mu \mathrm{M}$ of 7 , a concentration that caused ca $80 \%$ inhibition of proliferation. Mitochondrial kinetoplast was indicated by the arrow. Bar, $1 \mu \mathrm{m}$. 


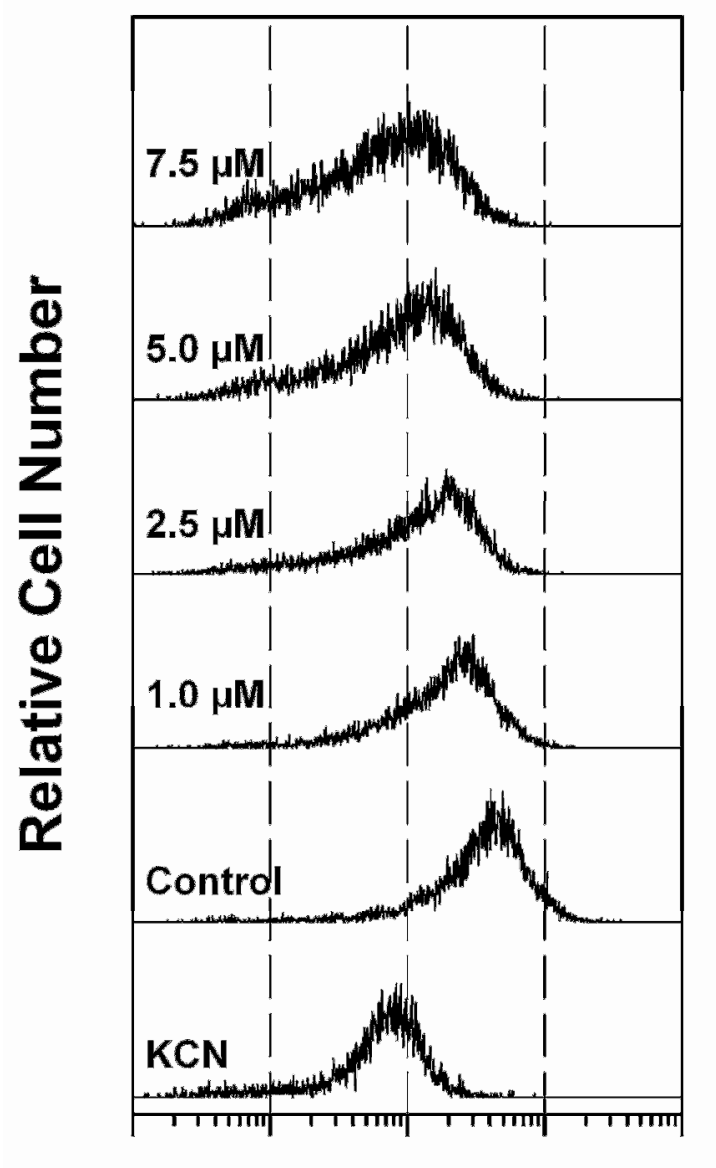

\section{$\begin{array}{lllll}10^{0} & 10^{1} & 10^{2} & 10^{3} & 10^{4}\end{array}$ \\ Fluorescence Intensity (a.u.)}

Figure 3. Variation of $\Delta \Psi_{\mathrm{m}}$ of $L$. donovani promastigotes monitored by rhodamine 123 accumulation. Parasites treated with 7 overnight as well as control cells were loaded with 0.3 $\mu \mathrm{g} / \mathrm{mL}$ rhodamine 123 and fluorescence level measured by cytofluorometry. Compound 7 concentration is shown at the side of each trace. Full depolarized parasites were obtained by incubation with $1 \mathrm{mM} \mathrm{KCN}$. 

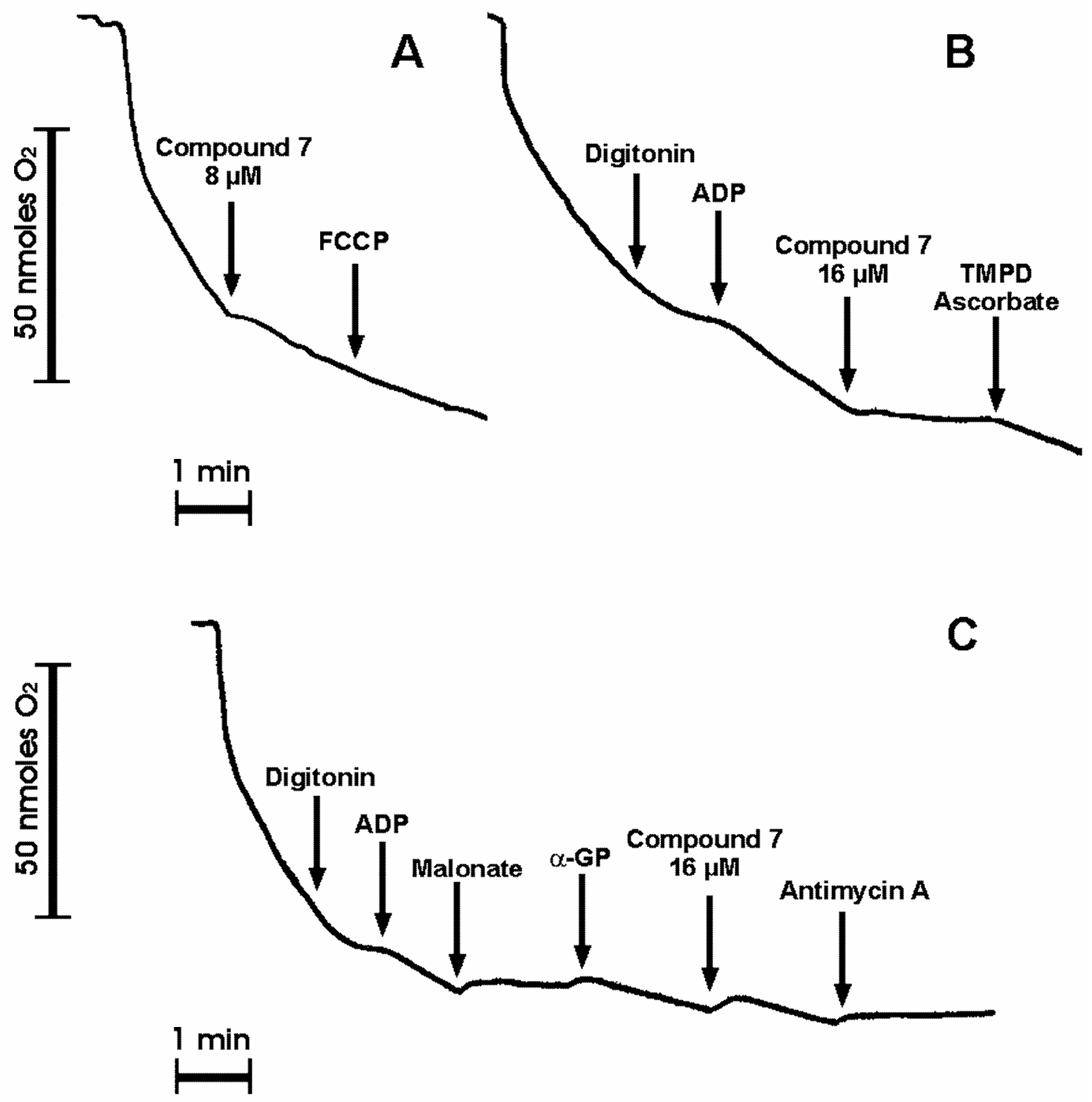

Figure 4. Variation of oxygen consumption rates of $L$. donovani promastigotes by 7. Bar scales for oxygen concentration ( $\mathrm{Y}$ axis) and time ( $\mathrm{X}$ axis) are included. Oxygen consumption rates were calculated from the corresponding slopes of the traces. Arrows stand for the addition of the indicated substrates and inhibitors at their respective final concentrations as stated: $10 \mu \mathrm{M} \mathrm{FCCP,}$ $60 \mu \mathrm{M}$ digitonin, $100 \mu \mathrm{M}$ ADP, $0.1 \mathrm{mM}$ TMPD plus $1.7 \mathrm{mM}$ ascorbate, $2 \mathrm{mM}$ malonate, $6.7 \alpha$ glycerophosphate ( $\alpha$-GP) and $1 \mu \mathrm{M}$ antimycin A. (A) Intact parasites, (B and C) digitoninpermeabilized promastigotes. 


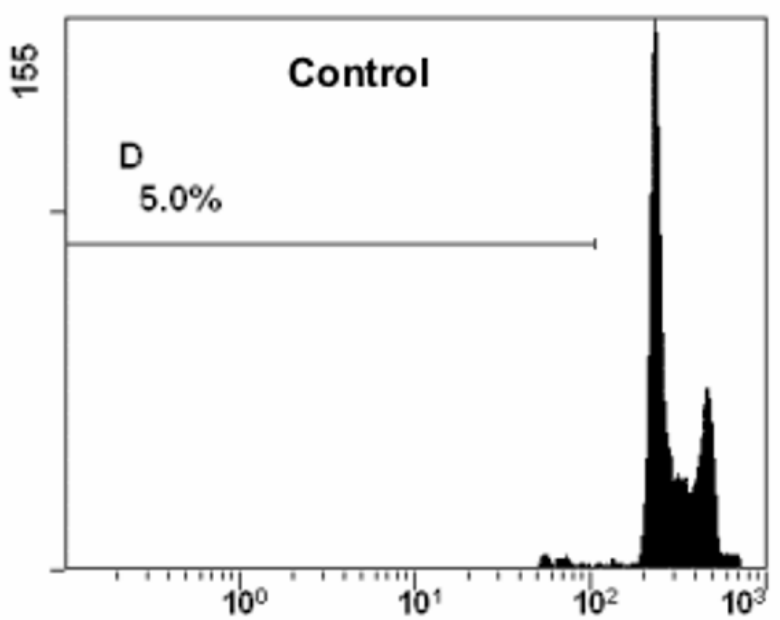

Fluorescence Intensity (a.u.)

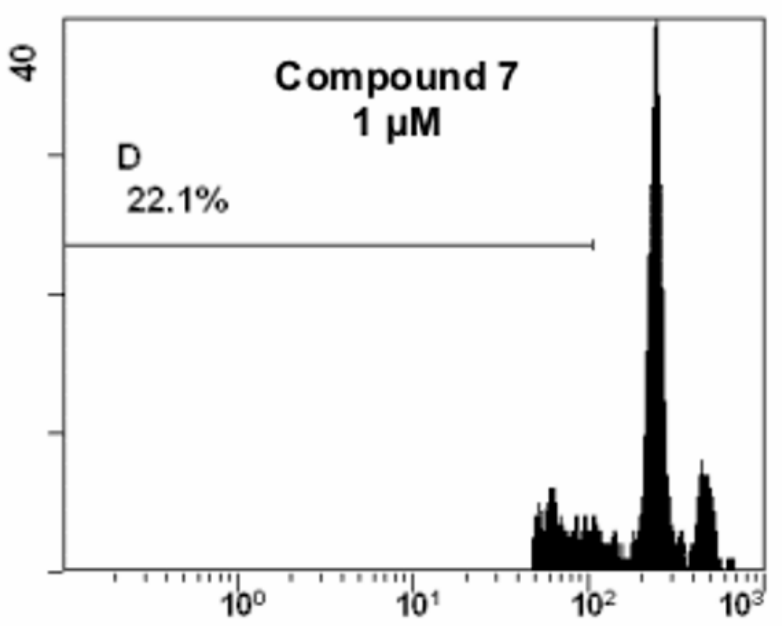

Fluorescence Intensity (a.u.)

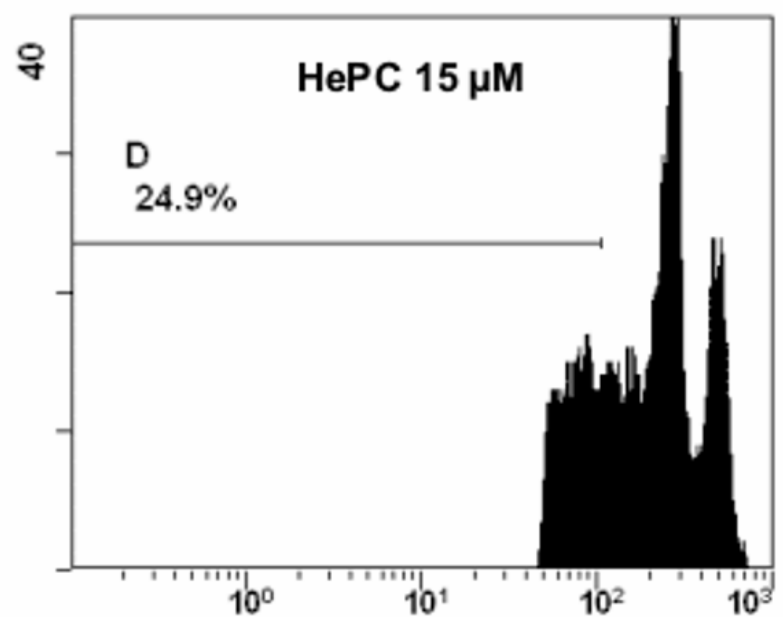

Fluorescence Intensity (a.u.)

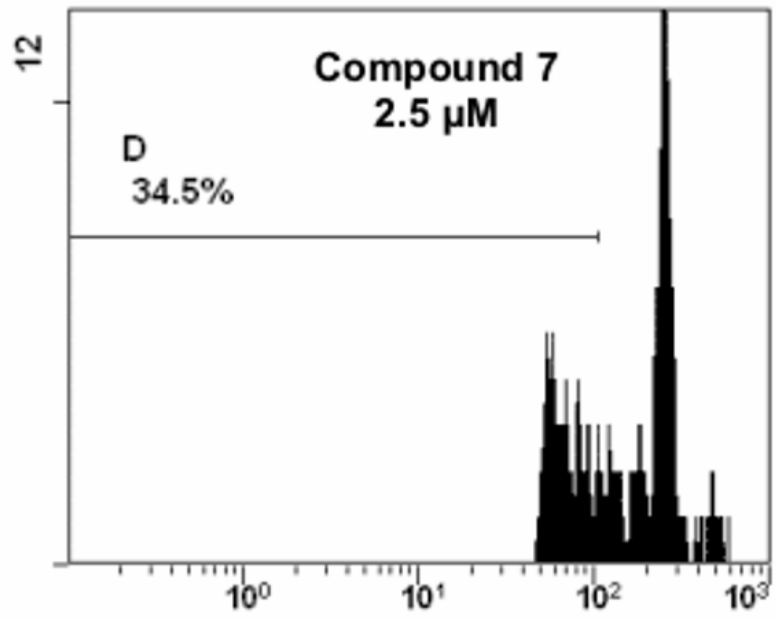

Fluorescence Intensity (a.u.)

Figure 5. Assessment by cytofluorometry of apoptosis in L. donovani promastigotes treated with 7. The presence of a sub- $\mathrm{G}_{1}$ peak, characteristic of the apoptotic cell population, was identified by nucleic acid staining with PI, and their percentage (D) indicated in each histogram 
Scheme 1.
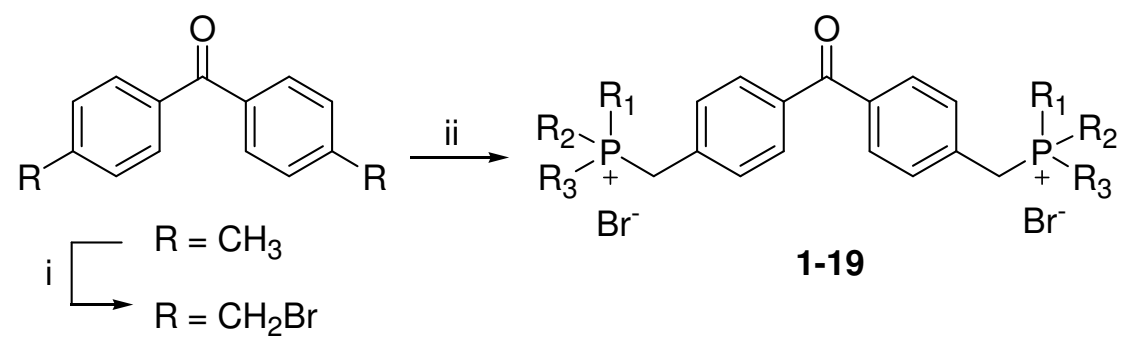

${ }^{a}$ Reagents and conditions. (i) NBS, Benzoyl peroxide cat., $\mathrm{CCl}_{4}, 80^{\circ} \mathrm{C}$; (ii) $\mathrm{R}_{1} \mathrm{R}_{2} \mathrm{R}_{3} \mathrm{P}, \mathrm{DMF}$ or toluene, $110^{\circ} \mathrm{C}$. 


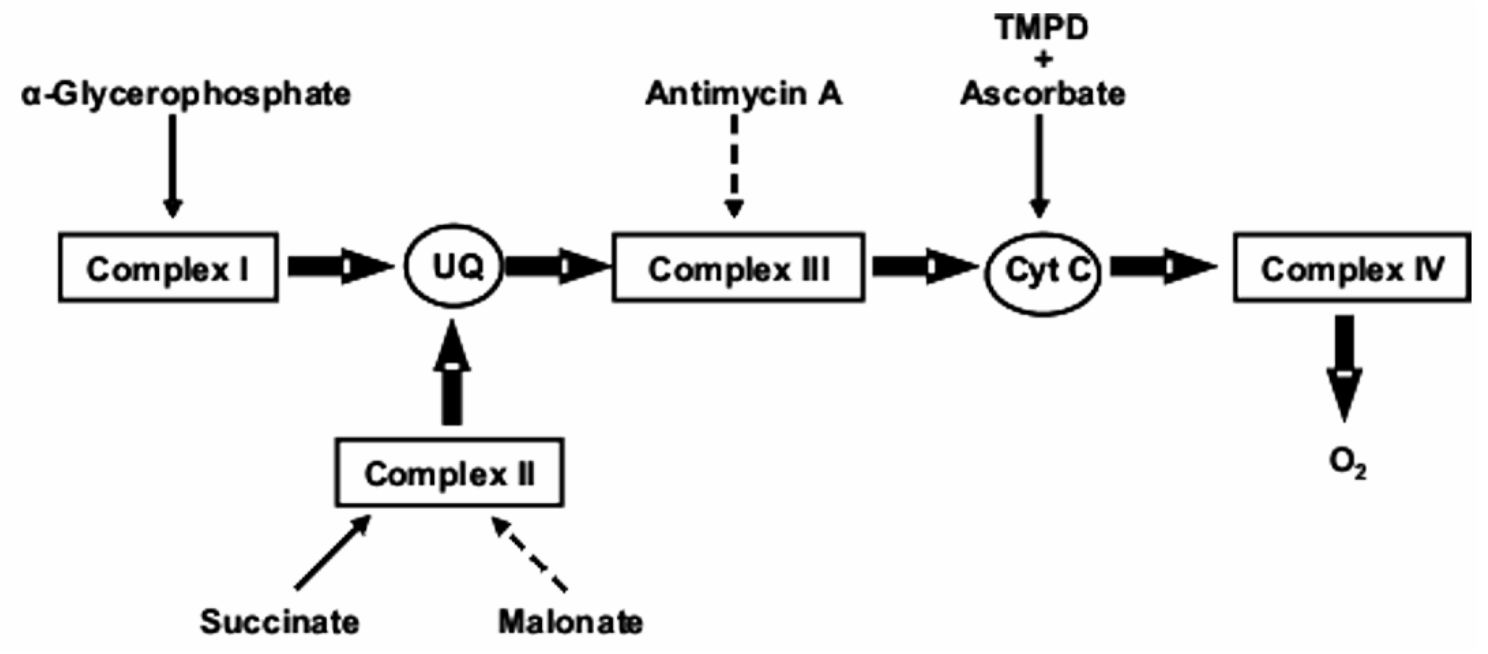

Scheme 2. Scheme of the respiratory chain in Leishmania with the specific substrates and inhibitors used in this study. Sites of electron feeding or inhibition are indicated by solid or dotted lines, respectively. UQ, ubiquinone; Cyt $\mathrm{C}$, cytochrome c. 

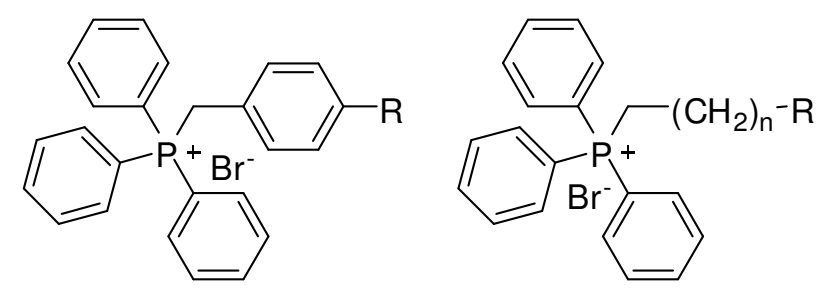

$$
\begin{array}{ll}
\text { I } R=\left(\mathrm{Ph}_{3}\right) \mathrm{P}^{+} & \text {III } \mathrm{R}=\left(\mathrm{Ph}_{3}\right) \mathrm{P}^{+} \\
\text {II } \mathrm{R}=\mathrm{CH}_{3} &
\end{array}
$$<smiles>[R7][PH2+]Cc1ccc(C(=O)c2ccc(C[P+]([R7])([R5])[R5])cc2)cc1</smiles>

Chart 1. Known triphenylphosphonium compounds with antischistosomal (I, III) or antitrypanosomal activity (II), and newly synthesized benzophenone-derived bisphosphonium salts (IV). 
Table 1. In Vitro Antileishmanial Activity and $\Delta \Psi_{\mathrm{m}}$ Variation Induced by Bisphosphonium Salts 119.

\begin{tabular}{|c|c|c|c|c|c|c|}
\hline & $R_{2} \backslash l^{R_{1}}$ & & $\mathrm{R}_{1}$ & $\mathbf{L C}_{50}$ & $\mu \mathrm{M})$ & $\% \Delta \Psi_{\mathrm{m}}{ }^{c}$ \\
\hline Compound & $\mathbf{R}_{1}$ & $\mathbf{R}_{\mathbf{2}}$ & $\mathbf{R}_{\mathbf{3}}$ & $\begin{array}{c}\text { L. donovani } \\
\text { Promastigote }^{a}\end{array}$ & $\begin{array}{c}\text { L. pifanoi } \\
\text { Amastigote }^{b}\end{array}$ & \\
\hline Miltefosine & & & & $12.50 \pm 2.90$ & $26.30 \pm 3.40$ & 75.00 \\
\hline 1 & $\mathrm{Me}$ & $\mathrm{Me}$ & $\mathrm{Me}$ & $>50$ & $>50$ & - \\
\hline 2 & Et & Et & Et & $>50$ & $>50$ & - \\
\hline 3 & $n-\operatorname{Pr}$ & $n-\operatorname{Pr}$ & $n-\operatorname{Pr}$ & $>50$ & $>50$ & - \\
\hline 4 & $i-\operatorname{Pr}$ & $i-\operatorname{Pr}$ & $i-\operatorname{Pr}$ & $>50$ & $>50$ & - \\
\hline 5 & $n$-Bu & $n-\mathrm{Bu}$ & $n-\mathrm{Bu}$ & $>50$ & $>50$ & - \\
\hline 6 & $i$-Bu & $i-\mathrm{Bu}$ & $i$-Bu & $>50$ & $>50$ & - \\
\hline 7 & $n-\mathrm{C}_{5} \mathrm{H}_{11}$ & $n-\mathrm{C}_{5} \mathrm{H}_{11}$ & $n-\mathrm{C}_{5} \mathrm{H}_{11}$ & $1.09 \pm 0.14$ & $0.97 \pm 0.01$ & 48.00 \\
\hline 8 & $c-\mathrm{C}_{6} \mathrm{H}_{11}$ & $c-\mathrm{C}_{6} \mathrm{H}_{11}$ & $c-\mathrm{C}_{6} \mathrm{H}_{11}$ & $3.30 \pm 1.19$ & $1.67 \pm 0.06$ & 42.00 \\
\hline 9 & $n-\mathrm{C}_{8} \mathrm{H}_{17}$ & $n-\mathrm{C}_{8} \mathrm{H}_{17}$ & $n-\mathrm{C}_{8} \mathrm{H}_{17}$ & $5.66 \pm 0.46$ & $1.37 \pm 0.05$ & 10.80 \\
\hline 10 & $\mathrm{Me}$ & $\mathrm{Me}$ & $\mathrm{Ph}$ & $>50$ & $>50$ & - \\
\hline 11 & Et & Et & $\mathrm{Ph}$ & $>50$ & $>50$ & - \\
\hline 12 & $c-\mathrm{C}_{6} \mathrm{H}_{11}$ & $c-\mathrm{C}_{6} \mathrm{H}_{11}$ & $\mathrm{Ph}$ & $2.10 \pm 0.84$ & $1.45 \pm 0.17$ & 83.12 \\
\hline 13 & $\mathrm{Me}$ & $\mathrm{Ph}$ & $\mathrm{Ph}$ & $19.31 \pm 0.64$ & $1.64 \pm 0.5$ & 100.00 \\
\hline 14 & Et & $\mathrm{Ph}$ & $\mathrm{Ph}$ & $6.90 \pm 0.50$ & $14.01 \pm 1.20$ & 100.00 \\
\hline 15 & $\mathrm{Ph}$ & $\mathrm{Ph}$ & $\mathrm{Ph}$ & $2.73 \pm 0.99$ & $1.53 \pm 0.03$ & 67.25 \\
\hline 16 & $\mathrm{Ph}$ & $\mathrm{Ph}$ & 2-pyridyl & $3.03 \pm 0.66$ & $2.58 \pm 0.30$ & 100.00 \\
\hline 17 & $\mathrm{Ph}$ & $\mathrm{Ph}$ & $o$-tolyl & $1.90 \pm 0.01$ & $1.51 \pm 0.05$ & 55.75 \\
\hline 18 & $\mathrm{Ph}$ & $\mathrm{Ph}$ & $p$-tolyl & $1.20 \pm 0.29$ & $1.38 \pm 0.02$ & 53.25 \\
\hline 19 & 2-furanyl & 2-furanyl & 2-furanyl & $18.12 \pm 1.20$ & $>50$ & - \\
\hline
\end{tabular}

${ }^{a}$ Promastigotes of L. donovani strain MHOM/SD/00/1S-2D; ${ }^{b}$ Amastigotes of L. pifanoi strain MHOM/VE/60/Ltrod. ${ }^{c}$ Percentage of rhodamine 123 accumulated in the promastigote mitochondrion after overnight incubation at the respective $\mathrm{LC}_{50}$, relative to untreated cells. 


\section{References}

1. Croft, S. L.; Sundar, S.; Fairlamb, A. H. Drug resistance in leishmaniasis. Clin. Microbiol. Rev. 2006, 19, 111-126.

2. Bern, C.; Adler-Moore, J.; Berenguer, J.; Boelaert, M.; Boer, Margriet D; Davidson, Robert N.; Figueras, C.; Gradoni, L.; Kafetzis, Dimitris A.; Ritmeijer, K.; Rosenthal, E.; Royce, C.; Russo, R.; Sundar, S.; Alvar, J. Liposomal Amphotericin B for the Treatment of Visceral Leishmaniasis. Clin. Infect. Dis. 2006, 43, 917-924.

3. Croft, S. L.; Engel, J. Miltefosine--discovery of the antileishmanial activity of phospholipid derivatives. Trans. R. Soc. Trop. Med. Hyg. 2006, 100 Suppl 1, S4-8.

4. Chappuis, F.; Sundar, S.; Hailu, A.; Ghalib, H.; Rijal, S.; Peeling, R. W.; Alvar, J.; Boelaert, M. Visceral leishmaniasis: what are the needs for diagnosis, treatment and control? Nat. Rev. Microbiol. 2007, 5, 873-882.

5. Dardonville, C.; Brun, R. Bisguanidine, bis(2-aminoimidazoline), and polyamine derivatives as potent and selective chemotherapeutic agents against Trypanosoma brucei rhodesiense. Synthesis and in vitro evaluation. J. Med. Chem. 2004, 47, 2296-2307.

6. Rodríguez, F.; Rozas, I.; Kaiser, M.; Brun, R.; Nguyen, B.; Wilson, W. D.; García, R. N.; Dardonville, C. New bis(2-aminoimidazoline) and bisguanidine DNA minor groove binders with potent in vivo antitrypanosomal and antiplasmodial activity. J. Med. Chem. 2008, 51, 909-923.

7. Dardonville, C.; Barrett, M. P.; Brun, R.; Kaiser, M.; Tanious, F.; Wilson, W. D. DNA binding affinity of bisguanidine and bis(2-aminoimidazoline) derivatives with in vivo antitrypanosomal activity. J. Med. Chem. 2006, 49, 3748-3752.

8. Kinnamon, K. E. Treating African trypanosomiasis with opt. substd. triphenyl-benzylphosphonium halide cpds.Patent US4187300-A, 1980.

9. Kinnamon, K. E.; Steck, E. A.; Rane, D. S. A new chemical series active against African trypanosomes: benzyltriphenylphosphonium salts. J. Med. Chem. 1979, 22, 452-455. 
10. Kinnamon, K. E.; Steck, E. A.; Hanson, W. L.; Chapman, W. L., Jr. In search of antiTrypanosoma cruzi drugs: new leads from a mouse model. J. Med. Chem. 1977, 20, 741-744.

11. Hanson, W. L.; Chapman, W. L., Jr.; Kinnamon, K. E. Testing of drugs for antileishmanial activity in golden hamsters infected with Leishmania donovani. Int. J. Parasitol. 1977, 7, 443-447.

12. Levi-Schaffer, F.; Tarrab-Hazdai, R.; Meshulam, H.; Arnon, R. Effect of phosphonium salts and phosphoranes on the acetylcholinesterase activity and on the viability of Schistosoma mansoni parasites. Int. J. Immunopharmacol. 1984, 6, 619-627.

13. McAllister, P. R.; Dotson, M. J.; Grim, S. O.; Hillman, G. R. Effects of phosphonium compounds on Schistosoma mansoni. J. Med. Chem. 1980, 23, 862-865.

14. Sim, E.; Cullis, P. R. ${ }^{31} \mathrm{P}$ nuclear magnetic resonance studies of cell membranes labelled with phosphonium phosphatidylcholine. FEBS Lett. 1977, 79, 340-344.

15. Sim, E.; Pasternak, C. A. The metabolism of the phosphonium analogue of choline in cultured cells. A useful nuclear-magnetic-resonance probe for membrane phosphatidylcholine. Biochem. J. 1976, 154, 105-111.

16. Kanazawa, A.; Ikeda, T.; Endo, T. Synthesis and antimicrobial activity of dimethyl- and trimethyl-substituted phosphonium salts with alkyl chains of various lengths. Antimicrob. Agents Chemother. 1994, 38, 945-952.

17. Kanazawa, A.; Ikeda, T.; Endo, T. Novel polycationic biocides- synthesis and antibacterial activity of polymeric phosphonium salts. J. Polym. Sci. Part a-Pol. Chem. 1993, 31, 335-343.

18. Kenawy, E. R.; Abdel-Hay, F. I.; Abou El-Magd, A.; Mahmoud, Y. Biologically active polymers: VII. Synthesis and antimicrobial activity of some crosslinked copolymers with quaternary ammonium and phosphonium groups. React. Funct. Polym. 2006, 66, 419-429.

19. Popa, A.; Davidescu, C. M.; Trif, R.; Ilia, G.; Iliescu, S.; Dehelean, G. Study of quaternary 'onium' salts grafted on polymers: antibacterial activity of quaternary phosphonium salts grafted on '4 gel-type' styrene-divinylbenzene copolymers. React. Funct. Polym. 2003, 55, 151-158. 
20. Tashiro, T. Antibacterial and bacterium adsorbing macromolecules. Macromol. Mater. Eng. 2001, 286, 63-87.

21. Ross, M. F.; Da Ros, T.; Blaikie, F. H.; Prime, T. A.; Porteous, C. M.; Severina, II; Skulachev, V. P.; Kjaergaard, H. G.; Smith, R. A.; Murphy, M. P. Accumulation of lipophilic dications by mitochondria and cells. Biochem. J. 2006, 400, 199-208.

22. Ross, M. F.; Kelso, G. F.; Blaikie, F. H.; James, A. M.; Cocheme, H. M.; Filipovska, A.; Da Ros, T.; Hurd, T. R.; Smith, R. A.; Murphy, M. P. Lipophilic triphenylphosphonium cations as tools in mitochondrial bioenergetics and free radical biology. Biochemistry (Mosc) 2005, 70, 222-230.

23. Murphy, M. P. Targeting lipophilic cations to mitochondria. Biochim. Biophys. Acta Bioenergetics 2008, 1777, 1028-1031.

24. Modica-Napolitano, J. S.; Aprille, J. R. Delocalized lipophilic cations selectively target the mitochondria of carcinoma cells. Adv. Drug Deliv. Rev. 2001, 49, 63-70.

25. Modica-Napolitano, J. S.; Aprille, J. R. Basis for the selective cytotoxicity of rhodamine 123. Cancer Res. 1987, 47, 4361-4365.

26. Modica-Napolitano, J. S.; Singh, K. K. Mitochondria as targets for detection and treatment of cancer. Expert. Rev. Mol. Med. 2002, 4, 1-19.

27. Saraiva, E. M.; Vannier-Santos, M. A.; Silva-Filho, F. C.; de Souza, W. Anionic site behavior in Leishmania and its role in the parasite-macrophage interaction. J. Cell. Sci. 1989, 93, $481-489$.

28. Kiderlen, A. F.; Kaye, P. M. A modified colorimetric assay of macrophage activation for intracellular cytotoxicity against Leishmania parasites. J. Immunol. Methods 1990, 127, 11-18.

29. Luque-Ortega, J. R.; Rivero-Lezcano, O. M.; Croft, S. L.; Rivas, L. In vivo monitoring of intracellular ATP levels in Leishmania donovani promastigotes as a rapid method to screen drugs targeting bioenergetic metabolism. Antimicrob. Agents Chemother. 2001, 45, 1121-1125. 
30. Martin, E.; Mukkada, A. J. Identification of the terminal respiratory chain in kinetoplast mitochondrial complexes of Leishmania tropica promastigotes. J. Biol. Chem. 1979, 254, 1219212198.

31. Paris, C.; Loiseau, P. M.; Bories, C.; Breard, J. Miltefosine induces apoptosis-like death in Leishmania donovani promastigotes. Antimicrob. Agents Chemother. 2004, 48, 852-859.

32. Asin-Cayuela, J.; Manas, A.-R. B.; James, A. M.; Smith, R. A. J.; Murphy, M. P. Finetuning the hydrophobicity of a mitochondria-targeted antioxidant. FEBS Lett. 2004, 571, 9-16.

33. Sheu, S.-S.; Nauduri, D.; Anders, M. W. Targeting antioxidants to mitochondria: A new therapeutic direction. Biochim. Biophys. Acta-Mol. Basis Dis. 2006, 1762, 256-265.

34. Murphy, M. P. Selective targeting of bioactive compounds to mitochondria. Trends Biotechnol. 1997, 15, 326-330.

35. Wang, J.; Yang, C. T.; Kim, Y. S.; Sreerama, S. G.; Cao, Q.; Li, Z. B.; He, Z.; Chen, X.; Liu, S. ${ }^{64} \mathrm{Cu}$-Labeled triphenylphosphonium and triphenylarsonium cations as highly tumorselective imaging agents. J. Med. Chem. 2007, 50, 5057-5069.

36. Kim, Y.-S.; Yang, C.-T.; Wang, J.; Wang, L.; Li, Z.-B.; Chen, X.; Liu, S. Effects of Targeting Moiety, Linker, Bifunctional Chelator, and Molecular Charge on Biological Properties of ${ }^{64} \mathrm{Cu}$-Labeled Triphenylphosphonium Cations. J. Med. Chem. 2008, 51, 2971-2984.

37. Álvarez-Fortes, E.; Ruíz-Pérez, L. M.; Bouillaud, F.; Rial, E.; Rivas, L. Expression and regulation of mitochondrial uncoupling protein 1 from brown adipose tissue in Leishmania major promastigotes. Mol. Biochem. Parasitol. 1998, 93, 191-202.

38. Mukhopadhyay, A.; Weiner, H. Delivery of drugs and macromolecules to mitochondria. Adv. Drug Deliv. Rev. 2007, 59, 729-738.

39. Díaz-Achirica, P.; Ubach, J.; Guinea, A.; Andreu, D.; Rivas, L. The plasma membrane of Leishmania donovani promastigotes is the main target for CA(1-8) $\mathrm{M}(1-18)$, a synthetic cecropin Amelittin hybrid peptide. Biochem. J. 1998, 330, 453-460. 
40. Glaser, T. A.; Utz, G. L.; Mukkada, A. J. The plasma membrane electrical gradient (membrane potential) in Leishmania donovani promastigotes and amastigotes. Mol. Biochem. Parasitol. 1992, 51, 9-15.

41. Zilberstein, D.; Philosoph, H.; Gepstein, A. Maintenance of cytoplasmic pH and proton motive force in promastigotes of Leishmania donovani. Mol. Biochem. Parasitol. 1989, 36, 109117.

42. Abu-Gosh, S. E.; Kolvazon, N.; Tirosh, B.; Ringel, I.; Yavin, E. Multiple triphenylphosphonium cations shuttle a hydrophilic peptide into mitochondria. Mol. Pharm. 2009, $6,1138-1144$.

43. Mehta, A.; Shaha, C. Apoptotic death in Leishmania donovani promastigotes in response to respiratory chain inhibition: complex II inhibition results in increased pentamidine cytotoxicity. $J$. Biol. Chem. 2004, 279, 11798-11813.

44. Luque-Ortega, J. R.; Martínez, S.; Saugar, J. M.; Izquierdo, L. R.; Abad, T.; Luis, J. G.; Piñero, J.; Valladares, B.; Rivas, L. Fungus-elicited metabolites from plants as an enriched source for new leishmanicidal agents: antifungal phenyl-phenalenone phytoalexins from the banana plant (Musa acuminata) target mitochondria of Leishmania donovani promastigotes. Antimicrob. Agents Chemother. 2004, 48, 1534-1540.

45. Tielens, A. G.; van Hellemond, J. J. Surprising variety in energy metabolism within Trypanosomatidae. Trends Parasitol. 2009, 25, 482-490.

46. Brown, S. V.; Hosking, P.; Li, J.; Williams, N. ATP synthase is responsible for maintaining mitochondrial membrane potential in bloodstream form Trypanosoma brucei. Eukaryot. Cell 2006, $5,45-53$.

47. Gupta, S. N.; Thijs, L.; Neckers, D. C. Divinylbenzophenone and poly(divinylbenzophenone): on the synthesis of rigid polymeric photosensitizers. Macromolecules 1980, 13, 1037-1041. 
48. Neckers, D. C.; Abu-Abdoun, I. I. p,p'-Bis((triphenylphosphonio)methyl)benzophenone salts as photoinitiators of free radical and cationic polymerization. Macromolecules 1984, 17, 24682473.

49. Chicharro, C.; Granata, C.; Lozano, R.; Andreu, D.; Rivas, L. N-terminal fatty acid substitution increases the leishmanicidal activity of CA(1-7)M(2-9), a cecropin-melittin hybrid peptide. Antimicrob. Agents Chemother. 2001, 45, 2441-2449.

50. Luque-Ortega, J. R.; Saugar, J. M.; Chiva, C.; Andreu, D.; Rivas, L. Identification of new leishmanicidal peptide lead structures by automated real-time monitoring of changes in intracellular ATP. Biochem. J. 2003, 375, 221-230.

51. Vercesi, A. E.; Bernardes, C. F.; Hoffmann, M. E.; Gadelha, F. R.; Docampo, R. Digitonin permeabilization does not affect mitochondrial function and allows the determination of the mitochondrial membrane potential of Trypanosoma cruzi in situ. J. Biol. Chem. 1991, 266, 1443114434. 
Table of Contents graphic.
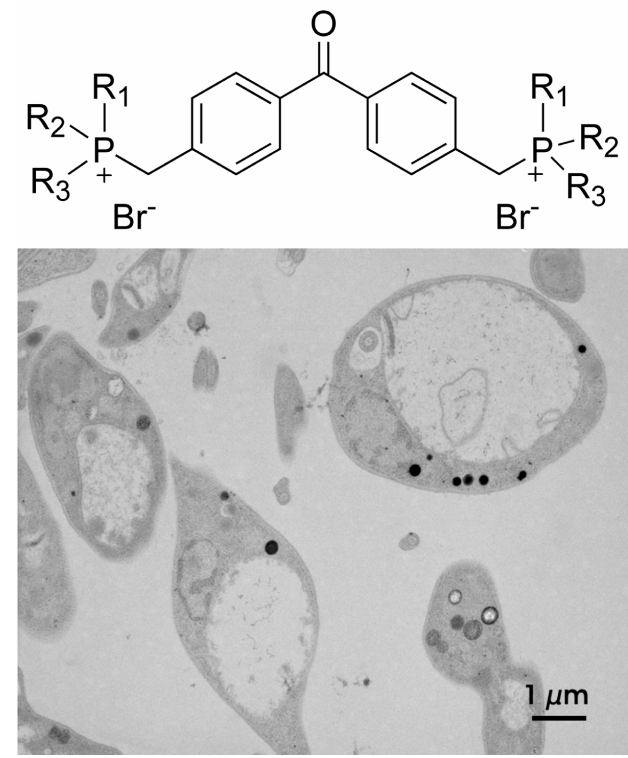